Historic, archived document

Do not assume content reflects current scientific knowledge, policies, or practices. 

UNITED STATES ENTOMOLOGICAL COMMISSION.

\section{Bulletin No. 5.}

\section{THE CHINCH-BUG.}

ITS HISTORY, CHARACTERS, AND HABITS, AND THE MEANS OF DESTROYING IT OR COUNTERACTING ITS INJURIES.

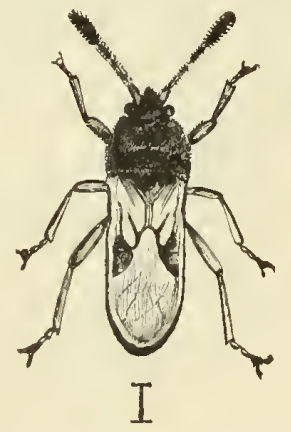

By CYRUS THOMAS, Ph. D.

WASHINGTON :

GOVERNMENT PRINTING OFFIOH. 1879 . 
(․ V. RILET, Chief,

Washington, D. C.

A. S. PACKARD, JR., Secretary,

Provillence, R. 1

(YRLS THOMAS,

Disbursing dgent,

Carbondale, III 


\section{LETTER OF TRANSMITTAL.}

Carbondale, Ill., December 6, 1879.

DEAR SIR: I herewith submit to the Commission for publication the mannseript of the Bulletin I have prepared, according to the direction of the Commission, on the history, description, and habits of the chinchbug, and the best means of destroying it or preventing its injuries.

Very respectfully,

Prof. C. V. Rilley,

CYRUS THOMAS.

Chief of Unital States Entomological Commission. 



\section{THE CHINCH-BU G.}

The ehineh-bug (Blissus lencopterus Say) is unquestionably one of the most formidable insect pests with which the farmers within the wheatproducing area of the United States have to contend. Although not execeding a grain of wheat in size, rather slow motioned, and possessing no other weapon of destruction than its tiny slender beak, yet the speeies is enabled to make up by number for the lack of individual capaeity for destruction.

The loensts of the west are the only ereatures of this class "whieh exist within the bounds of our national domain, whose multiplieation canses more sweeping destruction than does that of this diminutive and seemingly insignifieant inseet." In the territory east of the Mississippi it is without a rival.

Mr. Walsh estimated the loss from the ravages of this inseet in Illinois alone, in 1850 , at $\$ 4,000,000$, an average of $\$ 4.70$ to every man, woman, and ehild then living in the State.

Dr. Shimer says that it "attained the maximmm of its development in the summer of 1864, in the extensive wheat and eorn fields of the valley of the Mississippi, and in that single year three-fourths of the wheat and one-half of the eorn erop were destroyed throughont many extensive distriets, comprising almost the entire Northwest, with an estinlated loss of more than $\$ 100,000,000$ in the curreney that then prevailed."

Mr. Thomas, in his second report as State entomologist of Illinois, remarks as follows, in reference to the loss oecasioned by them in 1871: "I find no complaints of damage recorded in 1870 , but as the summer was dry over a large area, and they appeared in immense numbers in 1871 , it is more than probable that they began to increase in the latter half of the season."

As Dr. Le Baron has noticed somewhat fully in his second report their operations in 1871, it wonld be umnecessary for me to do more than adrert to it, were it not for the fuet that this second report does not appear to have been generally distributed and is rarely seen. The following quotation will suffice to show the extent and severity of this visitation:

"Some idea of the loss cansed by the deprerlations of this inseet, in this and neighboring States, may be realized when we learn that over a belt of territory 100 miles wide, commeneing in the western part of Indiana, and extending more than 400 miles west, embracing an area of more than 40,000 square miles, the great staple of spring wheat was redueed to not more than a quarter of an average erop, and in many plaees wholly destroyed; and that over the same territory barley was 
less than half a crop, and oats not more than three-quarters of their usual amount.

"The center of this belt appears to have been a little north of the center of the State, being abont on a line with the junction of Iowa and Missomi, and taking in a correspouding part of Southern Iowa and Nebraska and of Northern Missonri and Kansas. South of this belt winter wheat takes the place of spring wheat and barley, and the chinch-bugs, though present in considerable nmmbers, ceased to contuit any very serions damage. North of this belt, also, notwithstanding that spring wheat constitutes a leadiug crop, the bugs became gradually less numerous, and a tolerable crop of this grain was harvested. And yet all through Northern Illinois and the southern part of Wisconsin, these insects were numerous enough to damage the crop to some extent, and to excite the most serious apprehensions for the snceeding year.

"In order to obtain as correct an irlea as possible of the annonnt of loss snstamed by the agrienlturist from the depredations of this insect the past rear (1871), both in this ancl the Northwesteru States, I have made the following calculations, based upon the statistics of the Department of Agriculture, witl a reasomable estimate of the proportional damage caused by this insect to those crops mpon which they depredate. All such calculatious must necessarily be only approximately correct, and rery loose and extratagant conjectures have sometimes been indnlged in mpon the loss caused by chinch-bugs in former seasons of their prevalence. It has been nuy intention to keep within reasonable bounds', and, by giving the figures in the case, I give others the opportunity to review my estinates.

"Taling the returns of the Department of Agriculture, for the years 1869 and 1570 , for our guide, we may assmme the present anmal yield of whent in the state of Illinois to be $30,000,000$ of bushels, of oats $40,000,000$, and of barley $3,000,000$.

"The area scrionsly ravaged by these insects comprised, as we have above stated, about the middle third of the State. This section wonld bear its full proportional third of the wheat and oats, and at least onehalf of the barley raised in the whole State. This would give as the product of that part of the State ravaged by chinch-bugs $10,000,000$ bushels of wheat, mprards of $13,300,000$ bushels of oats, and $1,000,000$ bushels of barley. 'The proportion of these erops destroyed by chinch. bugs we have put at three-quarters of the wheat, one-lualt of the barley, and one-guarter of the oats. 'This will give as the amounts actially destroyed by these insects, $7,500,000$ bushels of wheat, 500,000 bushels if barley, and in round numbers, $3,300,000$ bushels of oats.

"If we make a cash cstinate of this loss, by putting the price of wheat at $\$ 1$ a bushel, barley at 50 cents, and oats at 25 cents, we shall lave an agregate loss of 11 wards of $\$ 8,500,000$ in the central third of the State of Illinois.

"In this estimate we have made no account of the injury done to corn thronghout the State, nor of the damage to small grains north of the central belt. Here the calculation becomes much more indefinite, but I believe it will be generally admitted to be a low estimate if we add, for this purpose, one-quarter part to the above aggregate of loss. This will unake the total loss cansed by chinch-bugs in the State of Illinois, in the year 1571 , upwards of $\$ 10,500,000$. If we assume an equal amonnt of loss for the two States of Iowa and Missomi combined, and another equal amonnt for the four States of Indiana, Kansas, Nebraska, and Wisconsin, we shall have a total loss in one year, in the Northwestern States, of 11 wark of $\$ 30,000,000$ fiom this one species of insect." 
The loss in 1874 was probably equal to that in 1864; and I think aetnally greater.

Professor Riley made a eareful estimate by eonnties of the loss in Missouri, which he found to aggregate the large sum of $\$ 19,000,000$. I made careful estimates of loss on eorn alone in Illinois by this insect in 1874. These estimates were based on different data, so as to form cheeks, the one upon the other, and the loss by drought was eliminated. The resnlt showed a loss of abont $\$ 20,000,000$ on this single cereal. The entire loss to the State that year by the operations of this pernicions insect were not less than $\$ 30,000,000$, or $\$ 11.50$ to each inliabitant.

If the loss in the two States, Missomri and Illinois, anomnted to nearly $\$ 50,000,000$, it is not probabie that the entire loss to the nation by this dimimutive insect in 1874 fell any short of $\$ 100,000,000$.

As the species appears to have a maximum of development abont every five rears, the foregoing estimates render it probable that the annual loss to the nation by its operations averages $\$ 20,000,000$

Is it possible to prevent this great drain npon the agricnltural industry of our comntry, or to materially lesien it ? To obtain, if possible, an affirmative answer to this inquiry is the olyject of the Commission. That this loss to a large extent may be prevented is eonfidenty believed; but to do this it is first neeessary to have the farmers of our country fnlly informed in reference to all that is known resjecting the characeteristies, life-history, and habits of the species; also in reference to the varions remedial measures whieh have been tried or suggested, and what the result has been so far as they have been tested. It is also necessary to inform them fully in reference to what co-operation is necessary, the plans that have been tried, and the resnlt.

Our object, therefore, in presenting this bulletin is to give a brief résumé of what has been ascertained up to the present time in regird to the history and habits of the ehinch-bng, and what remerlies have heretofore been tried or snggested. This is lone with the hope that the farmers thronghout our conntry will aid ns in this work, which the liberality of onr national Congress has ordered for the benefit of the agricultural interests of the nation, and ly testing practically the remedies snggested or others that may suggest themselves, and, informing ns of the results, enable us to deterunine the best possible means of connteracting this pest.

The early history of its operations in our country is briefly given by Dr. Fitch in his second report on the Noxions Insects of New York, from which we extract the following:

"It was just at the elose of our levolutionary struggle, or about the year 1783 , that this bug was first noticed as a depredator nyon wheat, in the interior of North Carolina. It was at first supposed to be identical with the Hessian fly, which at this time was making snch destruetion in wheat crops on Long Island and in New Jersey. Tro years before this, the British army, accompanied by a detachnent of its German anxiliaries, had marehed throngh North Carolina, and the battle 
of Guilford was fought. Mr. J. W. Jeffreys states (Albany Cultivator, first series, vol. vi, p. 201) that an aged and highly respectable citizen of Orange Comnty, North Carolina, informed lim that it was 'immediately after this event that the Hessian fly or Hessian bug destroyed their erops of wheat; and they believed and do believe to this day (1839) that those soldier's left the flies or bugs as they passed throngh the conntry.' The insects continned to increase and spread throngh the Carolinas and Virginia for several years. In 1785 the fields in North Carolina were so overrun with then as to threaten a total destruction of the grain (Webster on Pestilence, vol. i, p. 279). And at length the crops were so destroyed in some districts that they were obliged to wholly abandon the sowing of wheat. It was four or five years that they continued so numerous at this time.

"The only particnlar acconnt which was published of the insect and its habits at this period, of which we have any knowledge, appeared in London, in Yomng's Amnals of Agriculture, vol. xi, p. 471. It is from this notice of it, Kirby and Spence state, that they derive the information given in their Introduction to Entomology (p. 127, American edition), which is as follows: 'America suffers also in its wheat and maize from the attack of an insect, which, for what reason I know not, is called the chintz-bug tly. It appears to be apterous, and is said in scent and color to resemble the bed-bng. They travel in immense columns from field to field, like locnsts, destroying everything as they proceed; but their injuries are confined to the States soutl of the fortieth degree of north latitude. From this account the depredator here noticed should belong to the tribe Geocorise Latreille; but it seems very difficult to conceive how an insect that lives by snction, and has no mandibles, conld destroy these plants so totally.'

"Abont the year 1809, we are informed by Mr. Jeffireys that the chinch-bug again became so destructive in North Carolina that in Orange Connty the farmers had to abandon the sowing of wheat for two years, and according to his statement the insects were subdued thereby. At various other times, of which we hare no record, it has undonbtedly been abundant in that and the arjacent States, that section of country appearing to le its headqnarters.

"In 1839, we have acconnts of its having again become excessively numerous and destructive in Virginia and the Carolinas.

"The bug had now become so numerous in Carolina and Virginia that, with its continued inerease in 1840 , the total destruction of their crops appeared inevitable. The prospect was so alarming that Sidney Weller, of Brinkleyville, Halifax County, North Carolina, and others in his neighborhood, nuited in the spring of 1840 in pledging a liandsome snm as a prize for some feasible method to arrest the career of this depredator. But at this juncture Providence interfered to accomplish what no human agency could have effected. Instead of being dry, like the two or three preceding years, the snmmer of 1840 proved to be of an opposite character, and the ravages of this insect were at once suppressed.

"It was about this period that the chinch-bug began to be noticed along the Upper Mississippi and though the northen parts of Illinois. It made its appearance there simultaneously with the establishment of the Mormons at Nauvoo (1840-1844), and many ignorant people firmly believed they were introduced there by these strange religionists, and 'Mormon lice' became the name by which they were currently designated through that district."

The history of its operations in Illinois from the time it was first observed, in 1840, np to 1877 is given by the writer quite fully in his 
Second Report on the Noxious and Benefieial Inseets of Illinois. This may be briefly summarized as follows:

The first notice of it in the State was in 1840, when it appeared in the northwestern portion, near the Mississippi, and in Tarewell Connty. There is also reason to believe it appeared this or the following year in Saint Clair Connty. In 1844 it was somewhat injurions in Sangannon and some other sections. In 1845 it dirl extensive damage in Knox, Tazewell, Will, and some other counties. In 1840 it was observed in Cass County. In 1847 it appreared in Lyons Connty, Iowa. In 1848 it was observed in Lake County, Iudiana, but there is no mention of it that I can find in Illinois in $1847,184 s$, or 1849 . But it is more than probable it began to develope in 1849, as it appeares in destructive numbers in 18.50 over a large portion of Northern Illinois. Formirlable numbers appeared in Illinois and the adjacent portions of Indiana and Wisconsin in 1854 and 1855, especially the latter year. This, ancording to Mr. Willians, of Geneva, Wis., was its first appearance in that State, coming from the south. In 18.5.5 it did considerable injury in Mercer and DeKalb Counties and some portions of Southern Illinois. In 1857 and 1858 it was observed in linited sections of the State. In 1861 and 1862 it was reported by Dr. Shimer as doing considerable injury in the northwestern portion of the State. In 1864 the crops in Iowa and adjoining seetions of Illinois suffered largely from its attacks, as did also other portions of the Northwest. It again marle its appearance in Illinois in 1865 , but the season being wet the insects were destroyed. In 1868 and 1869 it appeared in linited numbers in the southern portion of the State, but its development was eut short by the wet weather. The year 1871 was marked by its aplearance in vast numbers over the Northwestern States; and, as heretofore stated, 1864 was also another noted chinch-bug rear.

The following brief notive of its history in other sections is given here, but this we expect to make more romplete in our second report.

From Professor Riley's seventh report as state Entomologist of Missoni, we learn that it appeared in that State as early as 1836 ; that it was more or less injurious in certain sections in 1854, 18.5, 18.56, 1857 , and 1859 ; that in 1866 it was quite destructive, als also in 1870 71 ; but 1874 was the year in which it was most injurious in this State.

From a eommunieation received from Mr. J. II. Wissler, of Lockille, N. U., we learn this insect was very destruetive in that state abont 1837, a date not mentioned by I)r. Fitch. The sime writer also states that "it was very troublesome about twenty years ago (185?)," at which time we learn by a letter from Mr. E. A. II Whorter, of Canten Connty, Georgia, that it injured the rice erop in that comnty, the only certain notice we have of its ippearance in that state.

Mr. W. J. Ross, of Stanley County. North Carolina, writes us that "these inseets were abundant and did much damage in that eonnty in 1837 and $1545 . "$ 
It appears from Dr. Fitch's second report that they were so numerous in Virginia and North Carolina in 1856, as to spread a general alarm from the mountains to the seaboard.

\section{NAMES AND DESCRIPTION.}

The chinch-bug is a small insect less than one-fourth of an inch long, its length nsnally not exceeding three-twentieths of an inch; its width something less than one half its length; rounded on the underside and flat above; of a coal-black color, with white wings which have a triangular., black dot on their onter margins. It belongs to the order HEMrPTERA and sub-order Heteroptera, to which group also belong the common bed-bug, squash-loug, and other similar true bugs. This species, like all the rest belonging to the order, has the montl prolonged into a slender, horny, jointed beak, usually turued unde the breast when not in use. With this instrument, and the slender needle-like setre inclosed within it, they puncture the bark, leaves, and stems of plants, and suck out their juices. 1t is in this way the ehinch-buy obtains its food. As it has 110 means of gnawing plints, and is so dminutive in size, it would appear to be incapable of nutlieting any very serious injury on regetation; but, as heretofore stated, what it lacks in indiridual capacity for inflicting injury is made up by the immense numbers which are occasionally developert. A muriad of tiuy pumps incessantly drawing a way the juices of a plant must in a short time cause it to decay and die.

Although, as we hare seen, the insect was known long before 18:31, yet it was not mit that year that it was scientifically deseribed by Mr. Say, who "took a single specimen on the Eastern Shore of Virginia." This description, mder the name Lygous leucopterus, was given in a small pamplilet on the Heteropterous Hemiptera of North Ameriea, published br Mr. Say at New Harmony, Ind., December, 1831, and is as follows:

"Lygeus lencopterus._Blackish, hemelytra white with a black spot. Inhabits Tirginia. Body long, blackish, with numerons hairs; antennæ rather short, hairs; second joint sellowish, longer than the thirrl, ulti-

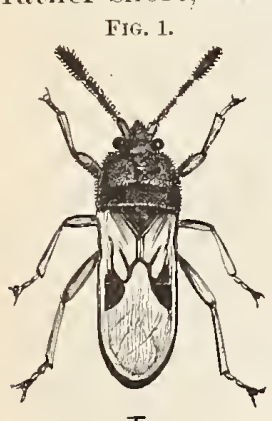

I

Chinch-buo. below shows the line ral length. mate joint longer than the second, thickest; thorax tinged with cinerous before, with the basal edge piceous; hemelstra (elytra) white, with a blackish oval spot on the lateral midulle; rostrum and feet honer-yellow; thighs a little dilated. Length less than three-twentieths of an inch."

Nineteen years afterwards Dr. Le Baron, not aware that the species had previously been described, named it Rhyparochromus dcvastator, and gave the following description in the Prairie Farmer of September, 1850:

"Length 12 lines or three-twentieths of an inch. Body black, clothed with a very fine grayish down not distinctly risible to the naked eye; basal joint of the antemne honer-yellow, sceond joint the same, tipped with black, third and fonth joints black; beak brown; wings and wing-eases white; the latter are black at their inser- 
tion, and have near the middle two short, irregnlar black lines, and a conspienous black marginal spot; legs dark honey-yellow, terminal joint of the feet and the claws black."

Numerous deseriptions of the young or larva have been given, but that by P'rofessor Riley in his seventh report is perlaps the most complete, and as it leaves nothing to ald, being ta'ken from fresli specimens and inchrding the egg, l copy it here, together with his excellent figure of" the preparatory stages:

"Egg-A rerage length .0:3 inch, elongate-oval, the diameter seareely one-fifth the length. 'The top' squarely docked and surmomted with four small, rominded tabereles near the center. Color, when newly laid, pale or whitish, and trans lueent, aecpuiring with age the amber color, and tinally showing the red parts of the enrbryo, and especially the eyos toward the tubereled end. The size increases some what af̣ter deposition, and will somestimes reach neatr .04 inch in length.

"Laveal stages.-The newly hatehed larva (Fig. D, o) is pale rellow, with simply an orange stain on the midldle of the three larger ablominal joints. The form seareely differs from that of the matture bug, being but slighitly more elongate; lut the tarsi have but two joints (Fig. $2, d$ ) and the head is relatively brouder and more rounded, while the joints of the body are suberual, the prothoracie joint being but slightly longer than any of the rest. The red rolor soon pervades the whole body, except the first two abdominal joints, which remain yellowish, and the nembers, which remain pale. After the first moult (Fig. ", e) the red is quite bright rermilion, contrasting strongly with the pale band across the midlle of the body, the prothoracir joint [first behind the hearl] is relatively longer, and the nectathoracie joint [thind behind the liead] shorter. The head and prothorax are dusky and coriaceous and two broat marks on the mesothorax [second joint behind the

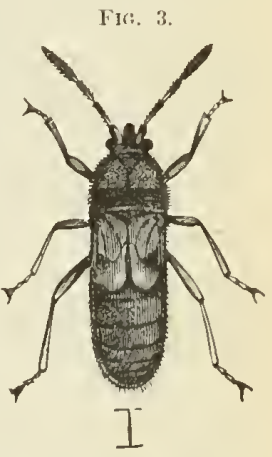

Short-wingerl Chinchhead |, two smaller ones on the metathorax, two on the fouth and fifth abrloninal sutmes, and one at the tip of the abdomen are generally visible, but sometimes obsolete; the third and formth joints of the autennie are dusky, but the legs are still pale. "After the second moult $[F i g . " 2, f]$ the head and thorax are quite dusky and the abdomen duller red, but the pale transverse band is still distinet; the winglouds become apparent, the members are more dusky, there is a lark red sharle on the fourth and fifth abdominal joints, and ventrally a distinct eirenlar dusky spot covering the last three joints.

"P'upra.-[Fig. '2,g]. In the pupa all the coriaceous parts are brownblack, the wing-parls extend almost across the two pale abdominal joints, which are now more dingy, while the general color of the abdomen is 
dings gras; the body above is slightly pubescent, the members are colored as in the mature bug, the three-jointed tarsus is foreshadowed, and the dark horny spots at the tip of the abdomen, both abore and below, are larger."

The characters of the perfect insect are so fully given in the descriptions by Say and Dr. Le Baron, alreadr quoted, that it is nunecessary for me to repeat them here. I may add that the antenne, which are not described, are a little less than half the length of the body, composed of four joints, the last being the largest. Dr. Fitch has also pointed ont the following varieties:

"a, immarginatus. - Basal margin of the thorax not edged with yellow. ish. Common.

" $b$, dimirlintus. - Basal half of the thorax deep relrety black, anterior half grayish. Common.

"c, fulvivenosus.-The stripes on the wing-covers yellow instead of black:

"d, albirenosus.-Wing-corers white, withont any black marks except the marginal spot. A male.

"e, apterus.-Under or true wings wanting, wing-cover's much shorter than the abdomen.

" $f$, basalis.-Basal joint of the anteme dusky and darker than the second.

"g, nigricornis.-First two joints of the antemure blackish.

"h, femoratus.-Legs pale livid yellow, the thighs tawny red. Common.

" $i$, rufipedes.-Legs dark tawny-red or reddish-brown."

Professor Riley adds another, melcuosus, "in which the usual white of the wings is quite dusky and contains additional black marks at the base and toward the tips, and in which all the members and the bods, except the rufous hind end of the thorax, are jet black."

It is but an act of justice to state that as early as 1845 (Prairie Farmer for October, 1845) Mr. J. Hadley gave the first brief description of the larvai state; although brief and making no pretensions to scientific aecuracy, ret the larval and pupal states are clearly incicated.

There is also occasionally seen in the northern sections a short-winged form of the perfert insect, such as is shown at Fig. 3.

The common name Chinch-bng is from the Spanish chinche, signifying bug. The name chints and chink bug were formerly occasionally nsed. As special notice was first called to them in Illinois, in the section and about the time the Mormons came to Nauroo, they were named "Mormon lice."

\section{NUMBER OF BROODS AND HIBERNATION.}

It was known soon after the insect became tronblesome that there were more broods than one, some, as Mr. Hadley, supposing there were "five or six generations." It is a quite common opinion, and is held by many to the present clay, that there are three broods. This belief arises very naturally from the fact that those which hibernate appear in the spring to deposit eggs; the perfect insects from these are counted as a 
seeond brood, the fall brood being the third, according to this method of counting; but, as will be seen by careful observation, those which appear in the spring are the same ones seen late in the fall. Dr. Shimer observed in 1864 and 1865 that this species is two-brooded, but no accomt of his observations were published until 186i. In the mean time, Professor Riley published the fact in 1866 that they are but twobrooded in the northern part of Illinois. Subsernent observations have shown this to be the rule in the other parts of the State and throughout the Northwest. There is some evidence of an occasional third brood in the extreme southern part of the State and in Kentucky, but not suffieient to justify me in asserting it as a fact or to satisfy me of its correctness.

Insects may pass the winter as eggs, which is a very common method; as larve or young, which is rather unusual; as pupx, which is a very eommon method in those order's where the pupa state is one of complete quiescence; and, lastly, they may pass the winter as perfect insects.

The last method is the one alopterl by the Chincli-bug. When cold weather comes on, those of the fall brood leave the now dry and hardened corn-stalks and seek secure places in which to renain during the winter. Occasionally they take flight at this time, but nsually they seek the most secure places which can be found in and immediately around the field. Any rubbish left in the field, if of a nature to meet their wants, is eagerly sought; corn-shocks, straw-piles, stmmps, logs, and fence-rows are used as hiding-places; they even hide beneath the clods when no better places can be found. Bit many move into the forest, grove, or woodland, if 'ither haplens to be near at hand. I have found also that the line of hushes along a little branch traversing the field is a farorite resort. Sheds, barus, railfences, and stacks often furnish them with winter quarters.

During the winter they remain in a torpid or semi-torpid state, but are easily warmed into life and aetivity. As the cold weather becomes more and more severe they press deeper and deeper, if possible, into the inner recesses of their hiding-places. They prefer dry quarters if readily obtained.

Whether the males survive in ermal numbers with the females is a point not ascertainerl, so far as I am aware, but I am of the opirion that the females are the more numerons.

Their time of coming forth in the spring depends upon the latitude ancl seasoll. In a few instances in unnsually early springs the have been seen as early as the midlle or latter part of March in the sonthern end of this State; while, on the other hand, in the northern part of the State in a late spring they have delayed their appearance until late in 'May, and probably eren intil the first of June. Usually they come out during the month of April in the southern and central part of the State. But it must be almitted that there is but little testimony on this point, as but very few of our farmers pay any attention to insects except when 
they beeome injurions or appear in immense masses. The ehinch-bug, when flying, wonld searcely be distinguished by the unpraeticed eye from a gnat. On this accomt our eorrespondence, and the printed and inanuseript notes we have examined, make far more frequent mention of the first appearanee of the young than they do of the spring appearanee of the libernating brood.

In order to show the varions hiding-plaees they select in whieh to hibernate, I quote the following notes fiom correspondents as found in my seend report:

"Wlen winter set in they went into winter quarters under eorn-shoeks, clods, rails, Se."

"I have nerer known them to winter in timothy or any tame hay; but if you want to raise an extra erop of bugs, leave a few bottoms of prairie-hay staeks and piles of eorn-fodder and straw until June, and, my wort for it, you will lave them."

"Their winter quarters are old rail fences, eorn-stalks, house-roofs, $\log s$, leaves, \&e."

In addition to these plaees, we may add that in timbered seetions they frequently go to the woods and seek shelter under the leaves and in the creviees of the bark of trees, under loose bark, and even hide mnder stones. I hare found them quite abundant in old stumps and old $\log$ s, and around fields whieh had been in corn during the summer previous. When no other hiding-plaee ean be found they will seek shelter firom the cold under clods of earth.

As the cold increases they will penetrate tarther and farther into their recesses. They prefer eomparatively dry situations, as moisture appears to be inimieal to them, thongh in this stage of their existence it does not appear to be necessarily destruetive of life as the following statement in my seeond report, given by a eorrespondent on whose veracity and intelligenee I can rely, will show:

"Ther have been taken from ice, by thawing it, and when slightly warmed would manifest signs of life, erawling about as in spring. They thus appear to be able to endure cold or heat."

I have often taken them in winter inclosed in a eovering of frost and to all appearanees frozen stiff, yet when plaeed in a warm atmosphere for a time they would survive. The following statenent by Dr. Henry Shimer, of Mount Carroll, Ill., in referenee to their winter life, will be interesting in this connection:

"After the early antumn firosts they left their feeding-grounds, on foot, in search of winter quarters; none eould be seen on the wing as at harvest time. For a winter retreat they resorted to any eonvenient shelter they might ehanee to find, as long grass, weeds, boards, pieees of wood, rails, fallen tree leaves, se.

"In Jannary, 1865, I next examined their eondition; those that I found in the sheaths of the eorn-leaves above the snow, and had been thus exposed during the previous severe weather-when for several suecessive days the thermometer was $15^{\circ}$ to $20^{\circ}$ below zero-were invariably found dead, without exception, and those beneath the snow were alive. This observation was made in the eommon farm eorn-tields, as 
they might be fomml anywhere all over the wide country, for in antumn the chinch-bngs remained in great numbers in the corn-husks and moler the sheaths of the blatles, as well as in other winter retreats. Upon varions occasions, as the winter advanced, I bronght in corn-hnsks filled with ice, inclosing the chinch-bugs in the crystallized element; when the ice was thawed they were able to run, appdrently unaffeeted by that degree of cold. It is therefore proved that these insects possess ritality sufficient to withstand the effect of a temperatme below the freezingpoint, and perhaps below zero, as munst have been their condition in these ice-bonnd liusks; bnt when in the open air, exposed to the sweeping pratrie winds, 15 or 20 degrees below zero, for a long time, they suecumb to the eold.

"March $7,186.5 .-T h e$ snow having celeared off" fiom the gromud, I ex. anined the condition of a host of these ehineh-bngs that hasl chosen for their winter covering eord-wood sticks lying on the gromnd, entirely sur. romeded by fiost and jee; of these 20 per cent. Were living; those that were more fortmate in their selection of winter quarters fincel much better. From a single hamdfinl of leaves picked nl) at one grasil from beneath an apple tree, I obtained 355 living and 31 'd dead chinch-bugs; and of their lady bird enemies that had entered the same winter quarters with them, 50 were living and 10 deanl. Of these chinch-bngs I placed a number in comfortable quarters in the house in a small pasteboard box-not in a stove room-tonether with some coleopterons insects easually gathered among the chinch bugs; after one month I found the latter all dead and the former living.

"The entire month of llareh was rain, smow, thawing, freezing, alternately, seening to be very mennfortable for any living creature to remain out of eloors with so poor a shelter and on top of the gromnd.

"April 1-6, 1 again male repeated exanninations of these chinch-bugs in their winter quarters, and fommd abont the simne proportion of them living as noterl on the ith of Mareh. At this time they wandered a way on foot from their winter quarters."

\section{TIIE FIRST BROOD.}

Inmediately after they come ont of their winter quarters in the spring, which varies, according to latitude and the season, from the latter part of March to the middle of May, they pair. Dr. Shimer states in the article from which we have just qnoted that he observed them at this time on the wing, which he appears to think is their usmal method during the time of their amons, but observations made by myself and other's do not confirm this opinion; on the contrary, they show it to be munsmal.

After pairing, the females commence laying their eggs, and nufortnnately for the firmer, nature appears to have made a speedal provision for them to adapt them to the vicissitndes of season, and even in reference to their method of oriposition. If compellet to deposit all their eggs at one time, an entire brood might be destroyed by a single drenching rain; but the female proceeds leisurely with her work, day by day depositing a few, those in her oraries developing as necessity demands, the process being earried on for two, or even three, weeks. According to the observations of Dr. Shimer, the usual time ocenpied in this work is abont twenty days, and the number deposited abont 500 . 
As a general rnle, the eggs deposited at this time are placed just below the smrface of the soil on the roots, or on the stem near the surface. The moisture of the soil at the time probably has something to do with the position ehosen, the higher being selected when it is lamp, and the lower when it is dry; the condition as to compactness or hardness donbtless has also something to do with the position selected. Dr. Shimer remarks that he "fomnd the chineh-bug eggs more abnndant mostly on the roots and stalks beneath the ground, sometimes in loose clusters of a dozen or more. They were on the roots, where they crossed the numerous eracks in the ground; less freqnently on the stem, at the smrface of the ground." Sometimes, as before intimated, this is. reversed, and they are more abmndant on the stem near, or just beneath, the surfaee than on the roots.

Numerons observations show that the eggs are more liable to be affected by climatic influences than the perfeet insects, and are sooner destroyed by heary rains. The moisture has the effect of dissolving the snbstance by which they are attached to the stalks, and the water earries them down into the moist soil and destroys their vitality. The following statement by Professor Ross, in the commnnication before alluded to, is quite interesting in this connection. His letter is dated June 4, 1875:

"Within the last week we have had two heary showers of rain. Before either of them fell I examined very carefnlly the eggs deposited abont twelve or fifteen days ago. They were very abundant on nearly every stalk of wheat, always deposited within one or two inches of the ground, in the sheath close to the stalk. There were probably an arerage of fifty eggs on the stalk. This evening, four days after the first examination, with a good glass, magnifying twenty-five dianeters, at hand, I examined the same field of wheat at the same place as my first examination. I found but few old bugs; some of the eggs had hatehed ont, but by far the greater nmmber of eggs were washed down from their places, distorted in shape, sunken into the soil, and many decomposed; probably not mure than one in ten of the first I saw had dereloped into a bug. I could easily tell the eggs that were destroyed. I examined many stalks on which I found no eggs. Abundant evidence is at hand in proof of their destruction in the egg state by rain."

The egg is at first of a pale dull whitish or testaceous color, bnt at length assumes a reddish color, from the changes transpiring within; the embryo can be seen as a red speck in the center through the transparent shell. When first hatched the roung bug is red with a white stripe across it; afterwards it turns of a brownish or grayish-brown color. Soon after it is hatched it inserts its tiny beak into the plant on which it is situated and commenees pumping ont the jnices on whieh the vigor and life of the plant depend. As their growth is rapid their molts are frequent; before reaching the perfect or winged state it passes through four of these changes, varying in color and markings after each. According to MIr. Riley's observations, "It is bright red, with a pale band across the middle of the body after the first; some- 
what darker with the merest ruliments of wing-pads after the second; and quite bown with distinet wing pads, but with the pale transiverse band still visible after the thind." The entire process leguines from five to seven weeks; according to I)r. Shliner's observations, from the time the egg is deposited mutil the imago appears is usmally fhom fifty-seven to sixty lays.

It is but a short time after they reach the perfect state-a few days only-before they pair, and the females deposit their oggs. The inseets produced from these constitnte the "fall" or "seeond brood," and pass through the same elianges as those of the first brool. 'The perfect insects of this brood, as before stated, live through the winter. In the sonthern part of this state, at least, it is not an mucommon thing to find the pupie wintering orer; whether those caught in this condition acquire complete wings in the spring is a question I am as yet nuable to answer. I have observed, as I think, a sinilar fict in reference to the eorn Aphis (Aphis mairlis); but in neither ease have I hat an opportunity of observing the final result.

\section{MIGRATIONS.}

Before the females of this brood deposit thein eggs they leave their original quarters and migrate in seareh of a more abundant supply of food. When this movement takes place it appears to be a very general one, and not, as sometimes supposed, solely for the purpose of enjoying the season of their amours or for depositing eggi, thongh these may be and doubtless are often in part the canse of this novenent. Abont this time the whrat becomes dry and hard, and no longer furmislies a supply of food; hence, they are necessarily forced to migrate or perisli. Oecasionally they take to Hight, and this appears to be more common some gear's than others, depending to a great extent npon the state of the weather, and perliaps to a certain degree npon being the time of their anours, as suggested by Dr. Shimer. liut the far more llsual amb almost universal methor is by marching along the surfice of the gromnd. There aplean's to be 110 uniformity in the dnection taken; in fact, they sometimes sat ter and go in different directions from the same field, but as a general thing the masses take one direction, which is toprards the nearest field of corn, oats, or some other coreal or grass that is still in a sucenlent state. In those seetions where corn is the chief or seeond ('rop' it is generally attacked. As the number of stalks to a given area is mueh less than in the wheat-field the forces are concentrated, and each stalk of corn receives the bugs of perhaps a humbred wheat-stalks. When the insects are very nmmerons the effect is soon visible.

In these nigrations the insects are by no means all matnred; often the majority have not advanced heyond the pupa state, but the want of nomrishment forces them to "go west" or in some other direction in search of food. In all snch movements mature and immatmre individuals 
will be observed. In some instances the numbers are so great that not only is the surfice of the gromnd literally covered, but they are piled on each other. If disposed to fly, which is not often the case, it sometimes becomes necessary to protect the nostrils of the horses at work in the fields. Those who have never witnessed a movement of this kind have a very faint idea of the immense numbers of individnals there are, aud the vast army of insects a single field of wheat has been feeding. Simply as a matter of curiosity I have made a ealeulation in order to ascertain the number of individnals on a given area. Snppose it to be the side of a field to rods long from which they were issning and that they covered the ground completely, but singly, for a width of one rod, this would give at least $175,000,000$ individnals. If the comfield attacked was 40 rods long, this would give abont 17,000 individnals to each hill for a depth of fifty rows.

The following qnotations will serve to illustrate this labit:

"When the dry straw of the wheat-fields no longer afforded them nourishment, they took up their line of march for the eorn-fields, literally covering the grom in many places; sontetimes gathering together into piles, and here easting their skins. This, being observed earelessly by farmers and others, leads them to declare that 'the elinch-bngs were destroying each other,' that 'they were lying,' se.; the dry shells remaining behind being mistaken for the insect itself.

"I have seen the colnmns of these insects a full week on the march across the meadows and pastmre-fields from the wheat to the corn field, and have even seen them swim a small stream of water that crossed their line of march. In former years the few border rows of corn, together' with the 'fox-tail grass' (Seturia), earelessly left among the corn in eultivating, nswally satisfied them. This latter grass is usually attacked m prefeience to the corn.

"In 1864, whole corn-fields were oremnn by them; the stalks, especially below the ears, blackly covered throngh the day, were bleeding and literally ran from their numerons pnnctmres. At length when they had attained the perfeet state dnring the warm part of loright snnny days, they took to their wings, and literally filled the atmosphere, not mnch mulike an April snow-storm. This interesting phenomenon indnced many to believe that they were leaving the comntry; but it was for an entirely different purpose-that of choosing their mates-for they never fly except in the love season. After a few days they might be fomnd paired in corn-fields and other proper breeding grounds, prodncing a new generation. At this time in the montlo of Angust, 1864, my attention was very favorably directed to a small field of tender, thickly-sown corn for fodder, where they congregated in immeuse mmbers, and continued until the frosts of antmm had killed the corn that they did not consmme, and developed their progeny in mmmnbered millions. During the day they resorted to the stalks of corn to feed npon the juice, but they passed the night usmally upon the ground."-(Dr. Shimer.)

Dr. Le Baron, in his first article pnblished in the Prairie Farmer in September, 1850, writes as follows:

"Meanwhile the grain, being deprived of its necessary nutriment becomes wholly blasted or much shrunken, whilst the straw turns white prematurely and at length crinkles down beneath the lancets of this infinity of phlebotomists. 
"When the wheat becomes too much dried np to afford them mutriment, they leave the wheat-field and may be seen at this time rmming mpon the ground in all directions in seavel of appropriate foor. Text to wheat they usmally attack oats, then corn, and lastly timothy or herds-grass; and if none of these are at hand, they will subsist mpon some of the wild grasses. The Indian corn is so rapid and rigorons in its growth that it is not nsually nuch injured; yet I have seen this season whole fields blackened with them, and large patches of corn blasted and prostrate, as if a fire had rum over them.

"They migrate from one fird to another by luming over the smaface of the earth. Nevertheless, when they ale olbligerl to move to a distance the perfect of winged individuals roadily take to Hight, and they have been seen flying in dense swarns."

The following interesting aceount of their nigrations, given by an fllinois former was published 11 the Proceedings of the New York Farmers' Club, oune, 1sio; :

"In passing by a field of batley where the chinch-lmgs had been at work for a week, I fomm them moving in solic rolumen across the roind to a corn-field on the opposite side, in such numbers that I felt almost afrail to lide my horse anong them. Some trams were at wolk mend

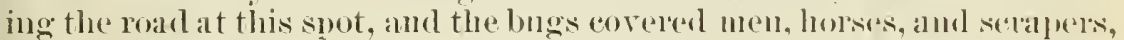
till they were forcerl to quit work for the day. The bugs took 10 acles of that corn elean to the gromm before its hardening stalks checked their progress. Another lot of them came firom a wheat-field arljoining my falm into a piece of corn, stopling now and then for a bite, but not long. Then they crossed a mealow 30 rods into a 16-arle lot of sorchlum and swept it like a fire, thongh the canc was then seance in tasiol. From wheat to sorghum was at least 60 lods. Their march was gorelned loy no discoverable law, except that they were infermally hmory and went where there was nost to eat. Helping a neighbor hisvest in one of the few fortunate fields, early sown, we fomd them moving across his premises in snch number's that they bir tinir to drive ont the finmily. Honse, crib, stable, well-curb, trees, garden-fentes-one ereeping mass of stinking life. In the house as well as ontsirle, like the lice of ligypt, they were everywhere; but in a single day they were gone."

Their migrations on foot seldom exceel so rods.

\section{NATURAL AGENCIES WHICII ASSIST IN THEIR DESTRUCTION.}

Many insects are subject to the attacks of enemies which appear to be adapted by nature to prey mon them. Enfortunately for our agrienltur. ists this little pest seems to he followed by no such relentless enemies as those that pursne the army-worm, plant-lice, Se. Even the camborous species whieh wage such an incessant wanfare against the rest of the insect tribes, appear to have little or no taste for snch an mistrory morvel as the chincl-bng, and if we judge them by on own nasal organs we cannot blame them. Still there are a few that now and then prey upon them, hnt even these do not appear to follow up the work very vigoronsly; nor are they snfficiently numerons to make any material impression on the vast hordes of these insects that oceasionally pervade onr grain-tields. 
The following statement; copied from Mr. Riley's serenth report cor er abont all that is to be said in reference to them:

"As long ago as 1861, Mr. Walsh in his Essays npon the Injurious Insects of Illinois, mblished facts which tended to show that four disFig.t. tinct species of ladybirds preyed npon the chinch-bug. The Wr first of these four is the spotted ladybird (Hippodamia maculata De Geer, Fig. 4), which also preys npon a great variety of other insects, attacking both the egg's of the Colorado potato-beetle and those of certain bark-lice.

"Iu corroboration of the fact of its preving on the chinch-bug" Spotterl Lady-birt.

I may state that the Rer. Charles Peabody, of Sulphmr Springs, informs me that he has repeatedly found it so feeding on his farm. The second species is the trim ladybird (Coccimella munda Say, Fig. 5) EIG. 5.

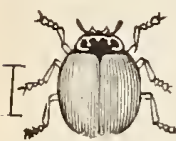
which is distinguishable at once from a great rariety of its brethren by having no black spots npon its red wing-cases. The other two are much smaller insects, belonging to a gemus (Scymmis) of ladybirds, most of the species of which are quite small and of obscure brown colors, and hard to be disTrim Ladybirl. tinguished by the popnlar eye from other beetles, the structure of which is very difterent, and which, therefore, belong to very diferent grouls and have very different habits.

"In the antumn of $186 \pm$, Dr. Shimer ascertained that the spotted ladybind, which has been slietched above, preys extensively mon the (shinch-bug. In a particular field of corn, which had been sown thick for fodder, and which was swarming with chinch-bugs, he found, as he says, that this ladybird 'conld be counted by hundreds mpon every square yard of ground after shaking the corn; but the ehinch-bugs were so nnmerons that these hosts of enemies made very little perceptible impression among them.'

"In the same antumn, Dr. Shimer made the additional discorery that in the very same field of fodder-corn the chinch-bugs were preyed upon by a rery common species of lacewing fly, which he described in Jantary, 186. as the Illinois lacewing (Chrysopa Illinoiensis). The description was republished, together with the substance of Dr. Shimer's observations, in the Prairie Farmer, of Chicago, Ill., accompanied with a non-characteristic wood-cut of the larra, cocoon, aud imago. At this time Dr. Shimer favored me with two specimens of the perfect insect, and he likewise furnished Mr. Walsh with additional specimens. From these specimens it is evident that the species is the same as that described long before by Dr. Fitch as the weeping lacewing (Chrysopa

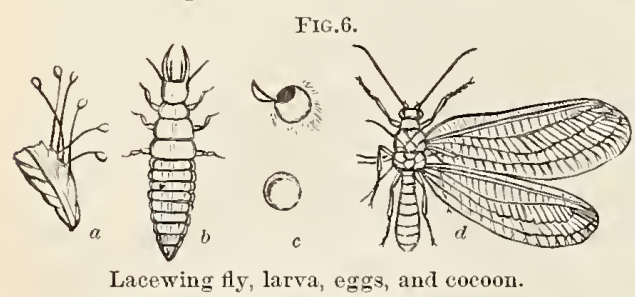
plorabunda), Fig. 6. In 1868, I found the same species quite nmmerons in a wheat-field belonging to Mr. T. R. Allen, of Allenton, where its larve were perhaps feeding on the chinchbugs, as they were fomnd to do in North Illinois by Dr. Shimer. The lacewing flies all bear a striking resemblance to one another, both in size, shape, and color. Almost all of them, in the fly state, have a characteristic and disagreeable odor, resembling nothing so mnch as human ordure.

"According to Dr. Shimer, the wceping lacewing fly was not quite as abundant as the spotted ladybird among the fodder-corn, but still there were so many of them that he thought that there was one or more of 
them for every stalk of that thickly-sown corn.' 'Every stroke of the cutter,' lie arlis, "wonld raise three or fonl dozen of them, presenting quite an interesting spectacle as they stagererel along in their awkwarl, matearly Hight.' And he not only actually observed the larvat preying very rolaciously on the chinch-bings in the field, bnt lie reared great mumbers of them to the matnre fly by feeding them npon chinch-bugs. His acconnt of the operations of the larrat when in captivity is so interesting that I quote it in full:

"I placed one of the larve in a vial, after having" eaptured it in the field in the rery act of deroming chinch-bugs of all sizes, and subsequently intodnced into the vial a number of chinch-bugs. They had hardly reached the botton before it seized one of the lingest ones, pierced it with its long jaws, held it almost motionless for about a minute while it was sncking the juices fiom the body of its riotim, and then threw down the lifeless shell. In this way I siw it destroy, in quick sncession, abont a dozen bugs. Tow mols the last, as its apuetite was beconing satiated, it spent five or more minntes in sucking the juices fion the body of one bing. Ifter this bonntiful repast it remained motionless for an honr or more, as if asleep. Never for a single moment dnring the feast did it panse in the work. When not in possession of a bug it was on a seareh for or in the pursut of others. It manifested much eagerness in the pulsuit of its pore, yet not with a lion-like boldness; for on several ocousions I observed a manifest timomonsmess, a halting in the attack, as if conseions of danger in its hunting experlitions, althongh here there was none. Some. times when two or more bugs were applodehing rapidly it would shrink back tion the attack, and tmumg aside go in the pursuit of others. At lengtl, awakening, it wonld renew the assanlt as hefore. On one occasion, when it was on the side of the vial, two inches 11p, with a lange hug in its unouth, I jarred the vial so that it fell to the bottom and rolled orer and orer acrosis the bottom, but, holding on to its prey, it reganed its footing and monnted

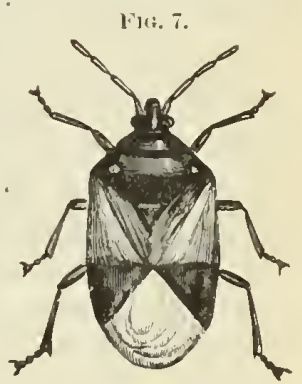

T

Insidious Flower-bug. up to its former position. Oceasionally the rhinch-bugs would hasten to escape when pursmed, as if in some deglee ronscions of danger.'

"The insidlions flower-bug (Anthocoris insidlosus Say, Fig. T), which is so often fomml preving on the leaf-inlabiting form of the grape P'hylloxera, and which is not unfrequently mistaken for the chineh-bug, is quite commonly fomm in commection with this last, and in all probability preys npon it.

"The many-banded robber" (Harpactor cinc. tus Fabl., Fig. 8) also preys npon the chinch. bng. It is quite frequently nuet with, and I have retected it in the act.

"The common quail of the Midrlle and Western States (Ortyx Virginiana), otherwise known as the partridge iol the Northern States, has long since been known as a most efficient destroyer

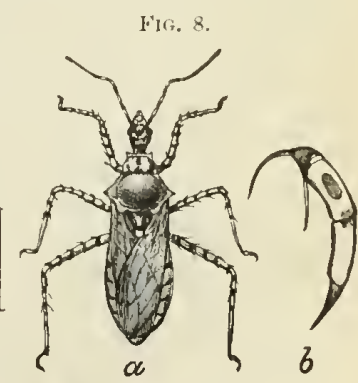

Many-landed robber. of chinch-bings and the fact was some time ago pmblished by myself in the Prairie Fanter, and by others in varions agrienl tural journals and reports. We also liare the corroborative testimony of Dr. Shimer, who is a good ornithologist. In the winter time, when hard pnsher for fool, this bird must devour inmense numbers of the little pests which winter in jnst snch 
situations as are frequented by the quail; and this bird should be pro tected from the gun of the sportsman in every state where the chinch-bug is kuown to rmu riot. It is gratifying to know that this fact has become sufficiently recognized to have gained for the bird legislative protection in Kansas. Prairie chickens are also reported as devouring it, but I do not know that any absolute proof has been given. Mr. J. W. Clarke, of Green Lake County, Wisconsin, also reports seeing the red-winged blackbird feeding on it.* Finally, Mr. B. W. Webster, of Anstiu, Cass County, and G. C. Biackett, Secretary of the Kansas State Horticnltural Society, have both written me to the effect that ants destroy its eggs."

The most efficient of these aids appears to be the Harpactor cinctus or banded-bug. I received in 1878 notice from points in the Northwest that it was doing much service in destroying chinch.bugs, but it does not develop in sufficient numbers to make any serious impression on them in the years they are abundant.

To the list of enemies given in the foregoing extract we may add the frog, which, according to Professor hoss and others, consumes a large number. Professor Ross goes so far as to express the belief that the destruction of these animals by draining their natural haunts is one reason why the chinch-bug is enabled to multiply as it does in some seasons.

As before stated, they are perhaps more seriously affected hy moisture than any other natural agency; and this faet has suggested to Dr. Fitch the idea of sprinkling, and to Mr. Riley irrigation, as remedies.

According to Dr. Shimer this species is occasionally subject to an epidemic disease that sweeps them away in immense numbers. The onlyknown instance of its appearance was in $\mathbf{1 8 6 5}$, as shown in the following quotation trom his article in the Proceedings of the Philadelphia Acar. ems of Natural Sciences heretofore mentioned:

"July 16.-A farmer four miles from here informed me that a black coleopterus insect was destroying the chinch-bugs on his farm rery rapidly; and although I found his supposition to be an error, yet I found many dying on the low ereek bottom-land from the effects of some rlis. ease, while they are set in the larva state-a remarkable and rare phenomenon for insects thus in such a wholesale manuer to be dying withont attaining their maturity, and no insect enemy or other efficient cause to be observerl capable of producing this important result.

"July 22.-On the low grounds the young chinch-bugs are all dead from the disease above alluded to, and the same disease is spreading rapidiy on the hills and high prairies.

"The weather has been very wet since the first of July, and the barley above alluded to, which I plowed beneath the ground, did not die, but assmmed a jellow, sickly appearance; in its shady, compressed, unnatural position, the ends of the heads project from beneath the furrows. The chinch-bugs also remained alive for a time, but feeding on the sickly grain and sharled from the sunlight, what little we had, were attacked by disease in the same mamer and about the same time as those on the low creek bottom-lands, meeting very rapidly the same fate, so that very few of them ever found their way to the neighboring corn.

"July 28.-Great numbers in all stages of their development are dying of the prevailing disease.

* Prairie Farmer, April 9, 1870. 
"August 8.-The majority of the chineh-bugs yet alive ale in the imago state, but they are being rapilly lestroyed by the prevaling epidenic rlisease, more fatal to them than the plagne or Asiatic diolera ever was to man, mole tatal than any lecolded disease :mong men or animals since time began. Seareely one in a thonsind of the vast hosts of rommg bngs observed at the millle of June ret remain alive, but plenty of dear ones may be seen evergwhere lymg on the ground, coveled with the common inoli of decomposing animal matter, and nothing else, even when examines by the microscope. Eren of those that migrated to coln-ficlds a few weeks ago, in such numbers as to cover the lower halt of the corn-stalks, very fow are to be found rem lining alive; but the gromud aromint the base of the corn-libls is almost literally corered with their moldering, decomposing deal bodies. This is a matter so eommon as to be observed and often spoken of by farmers. They ane dear everywhere, not lying on the ground alone, but sticking to the blades and stallis of eorn in great numbers, in all stages of their develop. ment, larva, pupa, and inago.

"August 22.-It is almost impossible to find even a few calinet specimens of chincl-bngs alive, so that I an quite sorry that I dicl not seenre a large supply of specimens while they were so munerons, in former years; for it really appears quite probable that eren eabinet speeinens will be hard to secure, whereby to remember the fallen race of the irnnumbered millions of former years.

"September 13.-It is generally believed anong entomologists that insect enemies are the most effieient means in nature for exterminating noxions insects; but in this remarkable fact in the history of insects the sreat epidemic of 186 is (there can be 110 doulut about this being an epidenic disease, becanse the insects died without at taining their maturity) we find a greater enemy, the greatest insect enemy eror recorded; a drearful plague, toat in a few days almost utterly amihilated a race of beings living in the northern part of the valler of the Mississippl, ontnumbering all the human beings that have ever lived on this planet since the nuorning of ereation.

"This disease among the chinch-bngs was associated with the longcontinned wet, elondy, eool weather that prevailed duming a greater portion of the period of their developnent, and doubtless was in a measure prodnced by deficient light, heat, and electricity, combined with exeessive humidity of the atmosphere, whoreby an imperfect physical (bug or fanization was developerl. The disease was at its maximmm dnring the moist walm weather that followed the cold lains of June and the fir'st part of July. The young ehinch-bug spent a great portion of jts time on or near the gromil, where its body was colıler than the atmos. phere; hence, upon philosophical principles, there must have been an excessive precipitation of watery rapor in the bronchial tubes. These are the facts in the case, bnt in the midst of the great obscurity that envelopes epidemic diseases anong men, it. would be only idle sjeculation to attempt to define the cause more detinitely than the physiologieal laws already observed seemerl to indicate. At all events it will requine many years of warm, dry summers, and accompanying winters of plenty of snow for protection, to reinstate the lost immmelable armies of this insect.

"During the summer of 1866 the chineh-bugs wele very searce in all the early sping, and up to near the harvest I was not able, with the most diligent search, to find one. At harrest I dicl snceeed in finding a few in some localities.

"This epidemie disease was not confined to the chinch-bug alone. Dur- 
ign the summer of 1865 . I saw the larve of the common striped cncumberbug (Diabrotica vittata) ou the stems of nelon ant cucumber vines, above ground, a very musnal place for them. Always before this I have found them on the root, leneath the snrface of the gromnd. This unusnal position was evidently to escape the effect of some nnnatural conditions. During the latter part of the summer of 1865 , the imagos were very much less numerous than common.

"The apple-worm (the larva of Carpocapsa (Tinea) pomonella L.) was very numerons in $1863-64$, affecting almost every apple. In 1865-'66, they were rely mnch less numerous. From observation I conclude that the disease was produced by the same cause that swept away the chinchbugs.

"The potato-worm (Sphinx quinque-maculatus) was very ummerous in 1864, doing much damage to tomatoes, \&e. The pupe were extremely abundant in the soil in the spring of 1865 , but in antum no observed larvie had survived.

"The Locustide (gimsshoppers) were also severely afflicted; the numerous rearl, of all states, were easily seen everywhere, clasping the gralss, weeds, \&e., in the embrace of death. I might add much more of my observations on these insects, and greatly extend the list of aftlicted species, but my object, to prove that epidenic diseases are incomparably the most important agents in all nature in destroying noxions insects, has been sufficiently illustrated. Teither is this a mere isolation, for I have observed diseases among various insects for the past twenty-five years."

Although the plague among the bugs in this instance appears to have been somewhat extraordinary, yet it is in accordance with facts ascertained in reference to other insects, and as Dr. Shimer is both a competent and reliable authority we accept his statement as correct, and believe with hin that it was owing as the originating canse to the damp season. But we are inclined to believe that the moistme gave rise to a mimnte fungns as the direct cause of the death of the chinches.

I recollect rery distinetly of a similar wholesale destrnction of houseflies in Sonthwestern Virginia and Last Tennessee in 1849, by an epidemic. So rapidly was the disease propagated and so great the destruction among the flies, which were umisnally abundant, that the ntmost cantion in cooking and in drinking water was necessary. Every moist spot was covered with the dead and dying. This I an satisfied was caused by a fungus.

I observed a somewhat similar epirlemic prevailing among the grasshoppers in Western Minnesota, Dakota, and Northern Iowa in 1872. All over the plains the dead were seen clasping the stems of grass and reeds, and before $I$ was aware of this fact more than once I approached cautionsly to capture a desired specimen, only to find it dead and rigid. In 1877 the rainy reason evidently caused an immense destruction of the larre of $C$. spretus.

\section{ARTIFICIAL REALEIES.}

As Dr. Le Baron in his second report as State entomologist of Illinois, which is now out of print, disensses somewhat thoronghly the subject of 
rentedies, I will quote in full his remarks before mentioning the remedies proposed by myself and others.

\section{"The plan of sowing grain so errly in the spring as to get in ardranee of their depredations.}

"The well known fact that winter-wheat generally matures before the young brood of chinch-bugs makes its alpearance, and thus escapes their ravages, natmilly snggested the idea that the same end might be accomplished with respect to spring-wheat, if the seed conld be got into the gromul very early in the spring. However plausible this supposition may appear, the experiences of the past season wonld seen to show that any reliance based npon it must prove, in a great measnre, fallacions. Sotwithstanding that the last spong was dry and favorable for the early sowing of ginin, and notwithstanding that it is miversally muderstood by farmer's that the earlier wheat can be sown the hetter for the crop, and therefore it may be presumed that wheat was sown munsually early, yet the result could scarcely have been more disastrous. I am not prepared to say that nothing can be gaincd by this comse, but in view of the experiences of the past scason, I lo not see how we can place much reliance upon this method of escaping the ravages of the rhinch-bug:

"In this commection we may advert to the plan of sowing certain stimulating substances, snch as salt aud lime, with the seed for the purpose of hastening the gonth and the ripening of the grain. It has also been supposed that a pretty lowe dressing with such materials might render the soil ohnoxions to the bugs. I have known of attempts being made to protect corn from the hugs, by the applieation of salt and airslacked lime, bnt withont any visible effect, and it is not probable that any quantity of such substances which we could reasonably apply to the soil would be effective in preserving our ('ops finm these insects. But in the other point of riew, that of hastening the ripening of the grain and thus placinge it in advance of the depredations of the bugs, this plan seems to me to be weell worthy of a trial. I was informed by a farmer living in Dixon that he tried sowing salt with his spring wheat, at the rate of one banel to two and a lalf acres, and that upon the field so treated the crop was much larger than on the ofluer portions, and ten or twelve days eallier. The effects of the salt will differ, of comse, to some extent, like ofler applieations, according to natme and condition of soil.

\section{"The rattempt to save a part of our erops by preventing the migration of the} bugs from one field to ruother.

"It is well kuown that when the small ginins become too matme and dry to afford nutriment to the chinch-bugs they nigrate in vast mumbers into the adjoining corn-fields, and generally destroy from a half dozen to a dozen or more of the outer rows, and nothing bint the great extent of the fields of the West and the exuberance of the plants, which at this time have nearly completed their growth, preserve the corn-erop from the same destruction which has overtalien the smaller cimins.

"As this migration takes place before the young bood have aconired wings, they necessarily travel on foot, and varions attempts lave been marle to intercept their plogress. The principal of these are a succession of furrows plowed across their path, and a barricade of fenceboards besmeared with coal-tar or kerosene-oil. The first plan, but very 
partially sncessful, is so simple and easy of execution that it is always worthy of trial. I was informed by sone farmers who practiced it the past season that it rery materially elieckerl their progress for the first day or two, so long as the furrow was fiesh and the earth friable; but that a shower of rain or heavy dew for a succession of nights so consoliclated the earth that the insects conld pass over.

"The other plan is much more effective, but also much nore tronblesome and expensive. It consists of a barricade of fence-boards placed end to end and set edgewise into the ground, with the upper edge besmeared witl sone offensive substance, the one most commonly used being coal-tar. This ntethod has been extensively resorted to the past season in the central part of the State, and especially in the neighborhood of the Bloomington gas-works, where the coal-tar is extensively manufactured. I was informed by one of the proprietors of the gasworks that nearly one hundred and fifty barrels of tar had been purclased at that establishment for this purpose. I had an opportunity of seeing this method put in practice, on a large scale, on the farm of Mr. Joshua Sells, of Bloomington. At the time of my visit Mr. Sells had discarded the boards as an mutecessary trouble and expense, and had adopted the simple and more expeditions plan of rumning a stream of tar from the spont of an old tea-kettle directly upon the gromnd along the exposed sides of his corn-fields. He foumd that a gallon of tar would extend abont ten rods, so that a two-gallon kettle twice filled would furnish a strij of tarred ground the whole length of a forty-rod corn-field. The tar had to be renewed every other day, and oftener in case of rain. The iusects would crowl up to the line in such numbers that in many places they would pile mp firom half an inch to an inch deep, and could be scraped n1, by the double haidful. But so long as the tar was kept fresh not a bug would eross it. They were not prerented from crossing by the adhesive nature of the tar, but by its repnlsiveness. The bugs wonld not tonch it. They were destroyed by courlucting them into perpendicular holes, or ly shoveling then in and burying them. The ustal price of coal-tar at the gas-works is abont two dollars a barrel. This is the most effective means ret resorted to for intercepting the progress of these insects when in the act of moving from one field to another; but the trouble and expense of nsing it, especially at a distance from the places where the tar is manufactured, will probably prevent its ever being rery generally practiced. The great deficiency of all such methods as a renedy for the chinch-bug is that, at best, they only protect that crop which is nsnally the least dam. aged by them.

\section{"The method of destroying the insects by burning corn-stallis and other rub-} bish in which they are supposed to hibermate.

"We have just adverted to the fact that when the small grains fail the ehinch-bues inigrate in to the corn, and that at this time they travel on foot and eontine themselves mostly to the outer rows. But shortly after this the young bugs aciuire wings and then spread themselves over the fields in large flocks. It is a question of considerable import. ance, and one to which but little attention has been praid, whether these insects materially damage the corn-crop after this general scattering of themselves, in the latter part of summer. From the circumstances of the case, this question does not admit of a very easy solution. The fact that these insects require comparatively little untriment after they have attained their winged and matnre state, taken in connection with the 
rast extent and luxmriance of the "exten eoln-fields, and with the addiional consideration that the crop, being at this time considerably adranced, the loss womld be only compunative and therefore not easily discriminated-all this tends to involve the suloject in much moertainty.

" Mr. George IT. Patten, of Inaran, Tazewell Comnty, at whose house I visited in the height of the chnch-bug season, actively co-operated with me in the determination of this and other matters apyertaining to these restrmetive insects. Mr. Patten took the pains to visit many of the farmers in his own and the neighboring connties, all of which were badly infested, for the purpose of making incmiries mpon this point. He foumd it to be the general opinion that the hows had damaged the crop very sensibly. Is the whole state has suflered severely the past season for the want of rain, there was the additional difficulty in this case of distinguishing between the effects of the dronght and that cansed by tine bugs. The inserts themselves, howerer, furmish a key to the solution of this diffienlty, by vintue of their gregarious habits. It appears that they do not seatter themselves indiseruninately over the field, bnt that they move in large flocks, not mulike their fellow-depredators, the blackbirds. Aceordingly the coln-fields are foumd to be dann. aged in patches, and it is thonght to a sufficient extent to materially diminish the arop).

"Thus general ditfinsion of the chinch-bugs orer the coln-fields after midsmmmer, taken in commection with the common observation that they remain there until late in the fall, has matmally sucrosed the expediency of gathering the stalks together and burning them, after the corn has been harvested, with the view of destroying the bugs. It has also been

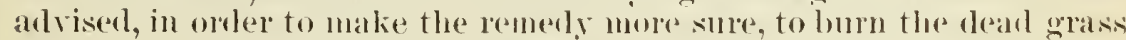

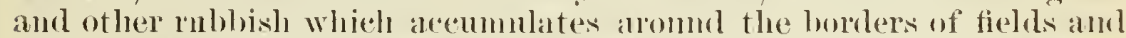
fences. My own observations have led me to the ronchsion that this remedy also, in the way that it would be likely to be generally put in practice, ean he of but little avail. Upon examining an intested comfield bate in Ootober, I foumd that the bugs had left the mpler part of the stalks and had collected abont the one or two lowrmost joints, muler the sheatlis of which they were congregated. They had gone thither partly perdaps to avoid exposme to the cold winds of approach. ing winter, bint chiefly, no donlot, for the sake of the nntriment which they could still extract firom the lower joints of the stalks after the mplepe ones had become dead and dry. Upon risiting the same field a month later (Novenber 202 ), after winter had virtnally set in, the mereury standing 150 above zero, the oromend whitened with snow, after cattle had lad the ange of the field, very few bngs condel be fomml. A few were fommd in deep eracks in the stalks, and a few wre lying torpid npon the gromen close to the roots of the corn. Epon digging nu) a number of hills no bugs conld be foumd beneath the surface. Where the great majority of them had gone was not aplalent. It is known that some of these insects hibernate nuder boards and that stones lying loosery npon the gromnd, and similat situations. Dr. Shiner fom in many of them moler the fallen leares of apple trees, but nearly half of these were dearl. I have heard of their being seen flying in Hocks towards the woods late in the fall. I cammot vonch for the truth of this, but I found them this fall in small mmber's moler the loose bark of prostrate loss, in the edge of the wools, half a mile from any tillage land. I also found them eongregated on the under sille of some that stones lying upon stubble land. Within a few rods from then was a ravine filled with long dead grass, but I could find no bugs anong the grass. It is proper to say, however, that this last was not a badly infested locality. 
"With the view of obtaining further observations upon this part of the subject, still later in the season, and especially in the badly intested district, I wrote to my friend Mr. Patten, whose assistance I have above been hapyy to acknowledge, and requested him to examine some of the corn-fields in his vicinity. From Mr. Patten's reply, under date of December 20, I extract the following valuable observations:

" 'Since the receipt of your letter, I have at different times examined coln-stalks with a riew to finding chinch-bugs, but have not succeeded in finding a live one. I have a piece of gromind sown to fall wheat, from which I had carried what few stalks of com the bugs had left standing, and had thrown them in heaps along the edges of the field. These heaps I have been examining, and have always font large numbers of dead bugs, but no live ones. To-day it occurred to me that perlaps by bringing them into a roon of proper temperature they might show signs of life; but after giving them a fair test I liave been unable to bring any to life. In all shocked corn that was put in shock before the frost killed the corn, I find large numbers of dead bugs, from the ear down. In later-cut corn ther do not secm to be so numerous. In the stalk-fields I find very fe" bugs, either dearl or alive. To-day I chopped up stalks by the roots, examining each sheath from the glound up); then opened the stalks, both sound and fractured ones, but found nothing that could be recognized as erer having been a chinch-bug. That the bugs disappeared fiom their usual hamits upon the approach of severe cold weather, I am fully satisfied, but wbere they now are I lave failed to ascertain. The first thought is that they have gone below the surface of the gromd; but when we consider that onr cold weather came so sudilenly upou us that the first night the ground was frozen to the depth of three or four inches, it hardly seems possible that the chinch-bugs could lave pene. trated it.'

" Mr. Patten made the following curious observation bearing npon the hibernation of these insects:

". About the time of our first frosts, while gathering hazel-nuts in the timber, I observed that in nearly every instance where a nut had been bored into by an insect or grub, from one to four ehinch-bugs had found their way into the mut. Whether they were there for winter quarters, or were feediug upon the partly-consumed nut, was a question which I could not solve.'

"Mr. Patten concludes his letter with the foliowing practical remarks:

"As to burning the stalks with a view to destroying the ehinch-bugs, I lave but little faith in it. Could the stalks be burned before excessive cold weather sets in, very probably a large portion of the bugs conld be destroyed, but by the time the coru can be harvested and the stalks are dry enough to burn, the chinch-bugs have taken to their legs or wings and left for parts unknown.?

"What strikes ns as remarkable in these statements of Mr. Patten is that all the chinch-bugs which he discovered appear to have been dead. The question arises, did they die a natural or unnatural death ? Had they arrived at the natural term of their lives, or were they lilled by the sudden accession of cold weather, or by some other and unknown cause? As many of these insects were found in tolerably well-protected situations, that is, under the sheaths of corn-stalks which had been laid in piles, it does not seem probable that they could have been killed by the first cold snap of winter. The most plansible explanation of the case I can give is that these dead insects were the old bugs of former broods which had arrivel at the end of their natural lives, whilst the instincts of the new brood, which are to perpetuate the race in the suc- 
ceeding rear, had led them to seek ont more secure and permanent retreats.

"From all this we conchnde that late in the fall, and when winter is about to set in, chinch-bugs, like most other insects, seek secnre and hidklen retreats where they will not be exposed to the suows of wintel nor the cold rains of the fall and spring, and therefore that the burning of eorn-stalks or other loose rnbbish, late in the fall, will destroy but a very small proportion of them. The only way to aceomplish this end to any considerable extent would be to husk the con'n as early as possible, and then ent off the stalks close to the gromnd and bum them. But even here it is very questionable whether the bugs would not leave the stalks before they were dry enongh to burn. But in any event, the plan is scarcely available in actual practice. In the first place, most farmers depend nyon their stalks for fall feal for their cattle; aud if a farmer shomld conchude to sacrifice his stalks for this pmrpose it wonld insme him 110 immmity from the inroads of the insects in the spring from surromuding localities.

"It may seem to be poor encomagement to show that the plans and preventives upon which we have been taught chicfly to rely, for check. ing the ravages of this formidable insect, are of little real effieaey. But it is best to know the truth and to see the evil in its trine proportions. The first step to take in meeting a real danger is to divest onrselres of all fialse securities.

\section{"The prevention of their breeding to any serious extent by abstaining from the cultivation of those grains upon which they chiefly subsist.}

"If, then, our supposed remedies for the chineh-bug prove in a great measure fallacious; if experience shows that we camot get on grain into the gronud so early but that the bugs will be evon with ns; if plowed furrows and tared barricades can only be resorted to when most of the misehief has been done; and if these insects hide themselves so secmely in winter that burning cornstalks and other rubbish can destroy, at best, but a very small proportion of them; and, finally, if their natmal enemies are so few as to make no pereeptible impression upon their conntless hosts, then we are driven to inquire, witl the more earnestness, whether we can take a step in arlvance of all these imperfect palliatives, and absolutely prevent the breeding of these noxions inseets, to any serious extent, by abstaining fon the cultivation of those erops which are most congenial to their luature. It may seem a hard alternative to give up the raising of some of oun most valuable crops at the behest of these nauseons Hemipter, but a hard remedy is better than no remerly. It is better to save your labor and your seed than to lose seed and labor and hairest likewise.

"What, then, does experience teach us with regard to the breerlinghabits of these insects and the plants upon which they mostly subsist?

"When the warmth of spring las become sufficiently confirmed to penetrate the hidden recesses where insects hibernate, many difforent species which have wintered over in the winged state are secul cmerwing from their retreats and lannching out upon the vernal air, apparenty rejoieing in their new lease of aetive existenee. Among these, in the localities where they prevail, the chinch-bugs are to be seen, flying in dense flocks, in seareh of the plants at the roots of which it is their in. stinet to deposit their egas. Mr. Sells, of Bloomington, informed ne that whilst plowing abont the first of May his elothing and his horses were thickly sprinkled over with then, and that the horses were 
serionsle annoyed in breathing by the bugs flying into their nostrils These insects deposit their eggs at the roots of our enltivated cereals and some of the grasses which most nearly resemble them. As the ehinch-bug is a native insect it must have subsisted originally npon the native grisses, before the enltivated cereals were introdnced. The ehinch-bug was then a rare inseet, only oceasionally met with by collectors. IIr. Thomas Say, who spent twenty ycars in eollecting and deseribing insects in many parts of the United States and their Territories, first described the ehineh-bug from a single specimen, and the ouly one he had ever seen, and whieh was eaptured in the eastern part of Virginia. Bnt there is no diftienlty in obtaining speeimens now. We liave ourselves been the means of their excessive multiplieation, by furnishing them with a superabundanee of congenial food in the shape of our cultivated grains.

"But the question now before us is, mpon whieh of these grains do they thrive best, and will they thrive sufticiently upon all of them to multiply to a serions extent, or are they restrieted in their food-plants to sueh a degree that we have it in onr power to get rid of them at any time by abandoning the cultivation of some one or more of these grains.

"It seems remarkable that these insects should make a selection between plants so similar, both in nature and appearance, as are several species of what are known as the small grains. Yet abundant experience has taught us that they do make a very decided seleetion. It is known that they ahwars give a strong preference to spring wheat and barley, where these are at hand. Where these two grains are not available, they will oriposit npon either of the others, and perhaps to about an equal extent. We know this from the faet that all of these grains are sometimes eonsiderâbly injured where ehinch-bugs abound, and the chief reason, probably, why winter wheat does not suffer as much as spring wheat is that this crop gets nearly matmed before the new brood of bugs makes its appearmee, and aceordingly we sometimes see late pieces of "winter wheat ahmost as mueh damaged by them as the spring: wheat. But the main question is whether, if no spring wheat or barley be raised, the chinch-bugs will eontinue to thrive and multiply to exeess npon any other kinds of grain. The general opinion is that they will not. And yet a sufficient number of exeeptional cases oecur to throw some doubt upon the matter, and to induce some farmers to hold the opposite opinion. Chinch-bugs are, in some years, found in eonsiderable numbers in the southern part of this State, where the winter grains exclusively are raised. A number of eases, also, like the following, have eome to my knowledge:

" MIr. D. Veateh, of Livingston County, stated to me that winter wheat, oats, and coln were all seriously damaged in his neighborhood, thongh but little spring wheat was raised; and on his own farm a field of thirty-six acres of oats was not worth harresting, thongh no spring wheat had been raised in its vieinty for the last five years. And a somewhat similar ease was related to me by a Mr. Vail, of Tazewell County. More definite testimony is needed upon this subjeet. My opinion, from my present knowledge, is that sueh eases are rare and exeeptional, and perhaps eould be easily explained if we knew all the eireumstanees.

"From the foregoing observations we draw the following praetical eonclusions:

"1st. That it is useless to attempt to raise spring wheat or barley where chineh-bugs have been present in any eonsiderable numbers the preceding year, unless we have reason to believe that they have been killed off by heavy rains. 
"2d. That in case the season should be favorable to the propagation of the chinch-bug, we always have it in our power to get rid of these pests by the abandomment of these two kinds of grains for one or two rears. But to make this conrse effective there must be a concert of action by farmers orer a considerable section of comntry.

"3. That the presence of ehinch-bugs the preceding Jear will not prerent the lanising of corn or any of the wintel grains.

"4th. With regarl to oats, the testimony this far is that if this grain be sown where chinch-bugs abomml, and especialls if it be somn exclnsively, it will be damaged to a wreater or less extent the first rear, brt that the bngs probably will not contime to breed in it to any great extent in sncceeding years.

\section{"Other proposed remedies.}

"It may be proper before closing to arlort brictly to a few of the nore plansible of the other remedies for the chinch-bug which have besen suggested. It has becul proposed to bmon over the infesterl and ruined grain fields just before the time for the bugs to leave them, with the riew of destroving the bugs and thus preventing their migration into the corn. This is a good sugegestion, porided the ganin is ory enomgh to burn before the bugs leave it; and, also, providerl it will bum low enongh to kill the bugs, which in this case wonld all drop to the gromud. The plan would be most likely to succeed by the aid of diy straw and tavorable condition of wind and dionght.

"Another plan which has been proposed is to sow a small poportion of winter rye (one bushel to twelve) with the spring whent, with the expectation that the hugs would feed upon the green rye near the gromel, whilst the more rapidls growing wheat wonld rise above it and come to maturity. This suggestion is tommled mpon the mistaken motion that the chinch-bnes feed mpon the green blades of the grain, whereas they imbibe their motriment, first fiom the roots, and afterwards from the lower joints of the stalk.

"The well-attested tact that chinch-bugs are checked in their operations hy rain indeced Dr. Fiteh to advise the sprinkling of wheat-ficks -or at least those parts of then where the bugs first male their appearance-with water, hy means of a garden engine, or some other contrivance. This would be an mteresting experincut whre the field is very small and the smpply of water abundant; but we presime the doctor would havdly recommend this plan as practicabo on the forty thomsand square miles of territory orerrm this year by chinch-bugs at the West.

"All the attempts to check the repredations of the chinch-bugs by throwing offensive substances npon them, such as tared saw-dnst, salt, or lime, have proved to be labor lost. The recommendation of salt application hat the run of the newspapers the past season. Both this and the air-slaked lime were thoroughly tried by $\mathrm{Mr}$. Sells, of Bloomington, without naking any pereeptible impression upon the bugs."

Mr. O. B. Nichols, of Clinton Connty, Illinois, writing to the Prairie Farner of December 2, 1858, gives the following as his plan for preventing their increase:

" Iy plan to keep clear of them is this: In the fall I plow under all the weeds and grass that I can get to with the plow. I have nuy fields so arranged that I can turn in my sheep and cattle to eat the weeds and grass out of the fence corner's before I sow my wheat, and in the bal. 
anee of my fields I turn on during winter, and if I have ans fenee eorners that 1 eannot feed ont, I take a toreh, and the boys follow with buckets of water and tin cups, and I burn up the grass and reeds. I feed all my com fodder and straw to $m y$ cattle and other stock, whether they need it or not. I leave nothing on the plaee after the 1st of May for them (the bugs) to harbor in."

Althongh long ago reeommended, and eonsidered of donbtful utility by so good an entomologist as Dr. LeBaron, it is in snbstanee, as will be seen hereafter, what the present writer eonsiders one of the most reliable pratical remedies yet suggested.

Dr. Fitel, speaking of measmres for destroying this pest or prerenting its injuries, remarks as follows:

"Nor has any mode for destroying this insect or preventing its depredations been discovered of such efficaer as to bring it into pnblie notice and favor. When they are migrating from one field to another, it has been reported that they have been arrested by digging a trench before them, up the ermmbling dirt of the sides of whieh they are nuable to elimb; and when the whole colony is thus imprisoned, they have been eovered with straw and burned. By burning the dry leaves of the forest in plaees where they have settled in numbers, multitudes have been destroyed. A subseriber to the Sonthern Planter (vol. xv, p. 275) says he knows that strong soapsuds will kill them, when sn eorn, if a half gill or gill be ponred on eaeh stalk; a labor not half so great as a single hoeing of the crop is. When this inseet beeane so mmerons in North Caroliua, in 1839 , Mr. J. W. Jeffreys proposed that the farmers aud planters shonld all abandon the sowing of wheat for two or three rears, he deeming this the only measure by which it was possible to subdne it. Dr. Le Baron thinks it improbable that any remedy ean ever bediseovered whereby to prevent its devastations. My own belief is very different. I do not think Providence has sent any injurions insect into our world but that when we cone to studs its history and habits, and become fully acquainted with its economy, we can discover some point where it is assailable, and hmman ingenuity will be able to devise methods by whieh it will be practieable either to destroy the insect or to shiekl the regetation on which it preys from its depredations, though often, no donbt, mnch patient investigation and many experiments, conducted by different persons, will be neeessary before we can arrive at the most eertain and snceessful rentedies.

"As regarls the chineh-bug, if the facts reported are true, we think they point us to a feasible node for subdning it. They indicate that moisture is most nncongenial to this insect. If, when it is overrumuing the land in myriads, a wet season arrives, it is at onee quelled in its career. Mr. Willians speaks of its ravages as having been perceptibly ehecked by a single heavy rain. And it appears from the statement of Mr. Albert Burnet that so slight a ciremustanee as the dew evaporating before the morning snu, first npon the sonth and rast sides of a field, often eanses it to eongregate upon those sides of the fieln exelnsively. In view of these faets it would seem that by drenching that part of a field in whieh these inseets are elustered with water, by means of a fire or a garden engine, they may be washed from the plants and destroyed. Thongh it will be a formidable task to shower a large wheat-field profusely, yet if the erop can hereby be saved from ruin, it will amply repay the expense. But commonly it is only a narrow strip npon one side of the field whieh will require this operation. And where there is a 
brook or strean of water passing through or adjacent to a wheat field, this measure can certainly be resorted to, repeatedly shonld it be necessary, at no great cost. Whem the snall red bngs, the tencler yomng larva of thesc insects, have made their appearance and are chustered about the roots of wheat plants in the month of June, they can probably be more easily destroyed than at any subsequent stage of their lives. And it is earnestly to be hoped that some one who is conveniently situated for testing the efficacy of this measure will do so and make the result known to the public."

Mr. Riley, althongh mentioning and discussing, in the article on the chinch-bug, in his seventh report, the varions remedies against this pest, lays particular stress on irrigation as a means of destroying it, remarking as follows:

"When a ficld of wheat or barley or rye is once overrun with Chinchbugs, man is, in the majority of cases, powerless before the musarory host, and his only hope is in tinely rains. The great majority of noxious inseets may be controlled even at the last homr, but a few-and among them is the Chinch-bug-defy our efforts when once they are in full force upon ns. There are several applications that will kill the insect when brought in contact with it, and I liave known a fow rows of corn to be saved hy the copious use of simple lot water; but the application of all such direct remedies becomes inr practicable on tle scale in which they are needed in the grain-fields of the West. Irrigation, where it can be applied-and it ean be in much of the territory in the vicinity of the Rocky Mountains, where the inscet commits sad havoc; and with a little effort, in many regions in the heart of the Mississipjoi valley-is the ouly really arailable, practicable remerly, after the bugs have conmeneed multiplying in the spring. I wish to lay particular stress on this matter of irrigation, believing, as I lo, that it is an effectual antidote against tlis pest, and that by overtlowing a grain-field for a couple of days, or by saturating the ground for as many more in the month of May, we may effectnally prevent its snbsequent injuries. In the article on the Rocky Mominain locust, I may lave something more to say on this matter of irrigation. We cannot at the critical moment expect nuch aid from is natural enemies, for these are few, and attack it mostly in the winter-time. WYe must, therefore, in our warfare witl this pest, depend mainly on preventive neasures where irrigation is impossible."

Having made observations in reference to the habits of this insect, and finding that it wintered in the perfect state, I suggested, in 1859, burning over the infested fields in the winter as perhaps the best means of destroying them, and am still inclined to look upon it as the best practical means of comnteracting them that is susceptible of general adop. tion. Irrigation is undoubtedly the most effective metlod of astroying them wherever it can be practiced, and should in such favored situations smpersede every other remedy. Unfortunately, in a very large part of omr territory where this insect proves most lestructive, this remedy is not feasible, and lence some other must necessarily be adopted. Bnt, as indicated in Mr. Riley's report, it is the only effectual means that can be resorted to in the spring after the bugs have commenced multiplying, unless the crop is sacrificed; lience the only plan the firmer can resort 
to, to counteract them, where irrigation is impossible, consists in prerentive measures. It is possible, as will hereafter be shown, to prevent n a large measmre injury to corn by the second brood, owing to the peculiar habit of the species of migrating on foot.

Before discussing further the remedies to be adopted, let us consult the statistical reports and see which of the two great products, wheat and corn, snffer most from the depredations of this pest, in order that we may know for which these remedies are most needed. For this purpose we will limit onr investigations to the Northwestern States, Indiana, Illinois, Missouri, Iowa, Wisconsin, Kansas, and Nebraska, and to the three great chinch-bng years 1864,1871 , and 1874 , as the statistics for these States and years are the most complete and will suffice for the object in view.

By taking the yield for the years 1870,1871 , and 1872 , we shall be able to detect any material variation in the crop of 1871.

We use the crop statistics of the Agricultural Department.

Total yicld of wheat.

\begin{tabular}{|c|c|c|c|}
\hline & 1870. & 1871. & 1872. \\
\hline 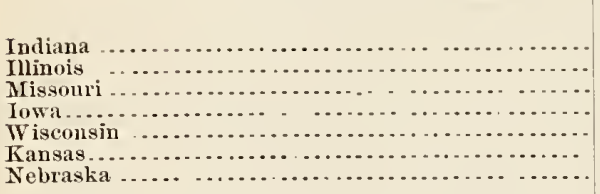 & $\begin{array}{r}\text { Bushels. } \\
20,200,000 \\
27,115,000 \\
6,739,000 \\
20,445,000 \\
20,485,000 \\
2,343,000 \\
1,848,000\end{array}$ & $\begin{array}{r}\text { Bushels. } \\
19,190,000 \\
25,216,000 \\
12,825,000 \\
18,400,000 \\
18,436,000 \\
2,634,000 \\
1,829,000\end{array}$ & $\begin{array}{r}\text { Bushels. } \\
19,381,000 \\
24,711,000 \\
7,695,000 \\
22,080,000 \\
22,307,000 \\
2,155,000 \\
2,500,000\end{array}$ \\
\hline 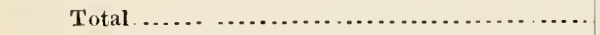 & $99,186,000$ & $98,530,000$ & $100,829,000$ \\
\hline
\end{tabular}

Field of wheat per acre.

\begin{tabular}{|c|c|c|c|}
\hline . & 1870. & 1871. & 1872. \\
\hline $\begin{array}{l}\text { Indiana } \\
\text { Inlinois } \\
\text { Missouri } \\
\text { Iowa } \\
\text { Wisconsin } \\
\text { Kansas } \\
\text { Nebraska }\end{array}$ & $\begin{array}{c}\text { Bushels. } \\
11.0 \\
12.0 \\
13.0 \\
12.5 \\
13.4 \\
15.0 \\
14.4\end{array}$ & $\begin{array}{c}\text { Bushels. } \\
12.0 \\
12.3 \\
13.4 \\
10.8 \\
12.2 \\
15.9 \\
10.3\end{array}$ & $\begin{array}{r}\text { Bushels. } \\
12.4 \\
12.1 \\
8.8 \\
12.6 \\
14.3 \\
11.6 \\
12.2\end{array}$ \\
\hline 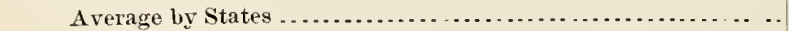 & 13.04 & 12.41 & 12.0 \\
\hline
\end{tabular}

Adopting a similar plan in reference to 1874, we find the yield of wheat in the same States, for 1873, 1874, and 1875, as follows:

Total yield of wheat.

\begin{tabular}{|c|c|c|c|}
\hline & 1873. & 1874 . & 1875. \\
\hline 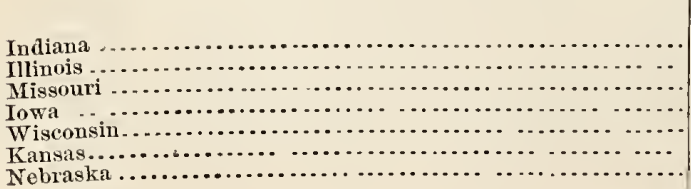 & $\begin{array}{r}\text { Bushels. } \\
20,832,000 \\
28,417,000 \\
11,927,000 \\
34,600,000 \\
26,322,000 \\
4,330,000 \\
3,584,000\end{array}$ & $\begin{array}{r}\text { Bushels. } \\
23,331,000 \\
30,122,000 \\
15,385,000 \\
33,908,000 \\
18,436,000 \\
9,455,000 \\
3,619,000\end{array}$ & $\begin{array}{r}\text { Bushels. } \\
17,280,000 \\
27,300,000 \\
11,160,000 \\
29,800,000 \\
25,200,000 \\
\text { (?) } 12,700,000 \\
3,400,000\end{array}$ \\
\hline Total $\ldots \ldots \ldots \ldots \ldots \ldots \ldots$ & $130,012,000$ & $134,256,000$ & $126,840,000$ \\
\hline
\end{tabular}


Field of wheat per acre.

\begin{tabular}{|c|c|c|c|}
\hline & 1873. & 1874. & 1875. \\
\hline Indjana . & $\begin{array}{l}\text { Bushels. } \\
11.2\end{array}$ & $\begin{array}{c}\text { Bushels. } \\
12.2\end{array}$ & $\begin{array}{l}\text { Bushels. } \\
9.0\end{array}$ \\
\hline (n) & 13.5 & 11.5 & 10.5 \\
\hline 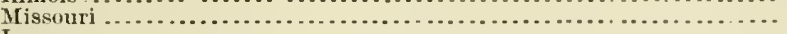 & 12.8 & 13.5 & 9.0 \\
\hline 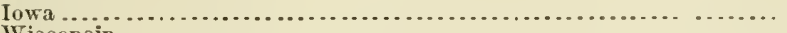 & 13. 0 & 11.6 & 9.7 \\
\hline 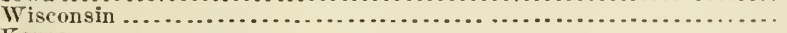 & 16.5 & 11.5 & 14.0 \\
\hline 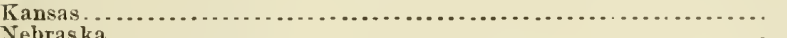 & 14.0 0 & 13.7 & (1) 17.0 \\
\hline 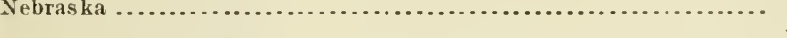 & & & \\
\hline Average by States .................... & 13. 79 & 12. 23 & 11.29 \\
\hline
\end{tabular}

It is apparent from a glance at these tables that there was no marked variation in the wheat-crops of the Northwest in 1871 and 1874, which can be attributer to the depredations of the chinch-bug. But before disenssing them we present the following similar tables in reference to the corn-crop:

Total yield of corn.

\begin{tabular}{|c|c|c|c|}
\hline & 1870. & 1871. & 1872. \\
\hline 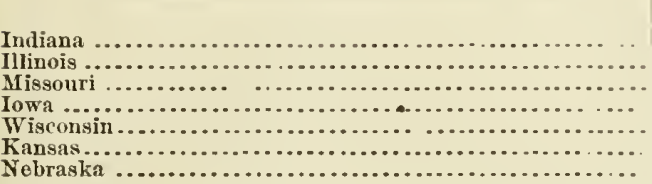 & $\begin{array}{r}\text { Bushels. } \\
113,150,000 \\
201,378,000 \\
94,990,000 \\
93,415,000 \\
19,995,000 \\
16,685,000 \\
5,163,000\end{array}$ & $\begin{array}{r}\text { Bushels. } \\
79,205,000 \\
203,391,000 \\
87,390,000 \\
99,019,000 \\
21,394,000 \\
24,693,000 \\
7,228,000\end{array}$ & $\begin{array}{r}\text { Bushels. } \\
85,541,000 \\
217,628,000 \\
105,741,000 \\
101,989,000 \\
21,180,000 \\
29,631,000 \\
7,589,000\end{array}$ \\
\hline 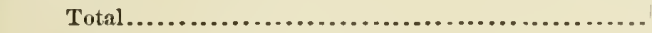 & $544,776,000$ & $522,320,000$ & $569,299,000$ \\
\hline
\end{tabular}

Field of corn per acre.

Indiana

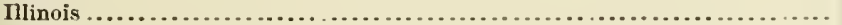

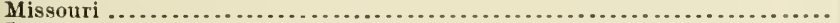

Iowa

$W$ isconsin

Nebraska

Average by States.

\begin{tabular}{|c|c|c|}
\hline 1870. & 1871. & 1872. \\
\hline $\begin{array}{c}\text { Bush. } \\
39.5 \\
35.2 \\
31.4 \\
32.0 \\
38.0 \\
28.0 \\
30.0\end{array}$ & $\begin{array}{c}B u s h . \\
35.7 \\
38.3 \\
38.0 \\
42.5 \\
37.7 \\
40.0 \\
41.5\end{array}$ & $\begin{array}{r}\text { Bush. } \\
38.7 \\
39.8 \\
37.0 \\
39.8 \\
38.0 \\
38.5 \\
37.8\end{array}$ \\
\hline 33. 44 & 39. 10 & 38.51 \\
\hline
\end{tabular}

Total yield of coru.

Indiana

Missour

Wisconsin

Kansas....

Nebraska

Total

\begin{tabular}{|r|r|r}
\hline 1873. & 1874. & 1875. \\
\hline Bushels. & Bushels. & \multicolumn{1}{|c|}{ Bushels. } \\
$67,840,000$ & $74,624,000$ & $\mathbf{9 5 , 0 0 0 , 0 0 0}$ \\
$143,634,000$ & $133,579,000$ & $280,000,000$ \\
$70,846,000$ & $46,049,000$ & $128,000,000$ \\
$105,200,000$ & $115,720,000$ & $160,000,000$ \\
$16,308,000$ & $15,492,000$ & $15,200,000$ \\
$47,000,000$ & $16,065,000$ & $76,700,000$ \\
$7,000,000$ & $3,500,000$ & $28,000,000$ \\
\hline $457,828,000$ & $405,029,000$ & $782,900,000$ \\
\hline
\end{tabular}


Field of corn per acre.

\begin{tabular}{|c|c|c|c|}
\hline & 1873. & 1874. & 1875. \\
\hline 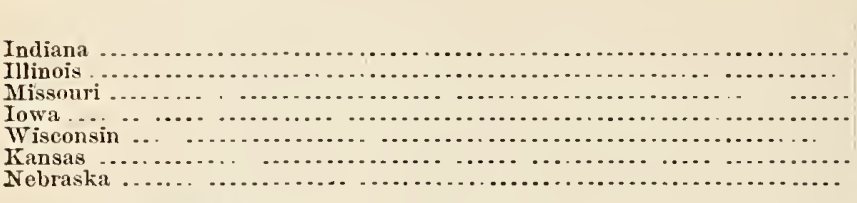 & $\begin{array}{l}\text { Bush. } \\
25.6 \\
21.0 \\
23.5 \\
29.0 \\
30.0 \\
39.1 \\
35.0\end{array}$ & $\begin{array}{l}\text { Bush. } \\
27.0 \\
18.0 \\
16.0 \\
29.2 \\
28.2 \\
10.5 \\
10.0\end{array}$ & $\begin{array}{r}\text { Bush. } \\
34.0 \\
34.3 \\
36.6 \\
35.0 \\
21.0 \\
40.0 \\
40.0\end{array}$ \\
\hline A verage by States. . . & 29.03 & 19.84 & 34.41 \\
\hline
\end{tabular}

Although fully aware that the crop statistics as given in the annual reports of the Agricultural Department are far fiom beng as accurate as desirable, yet they are as good as can be obtained by the means at the disposal of that department, and are moreorer onr only sonrce of information on the snbject. From some investigations I have made in my own State, I am inclined to think that as a rule they are in cxcess of the true figures, but on the whole approximate sufficicutly near the truc amounts for all ordinary or general purposes. I prefer, therefore, to rely upon them as a basis of calculation, rather than the unofficial statements given by others.

Taking these as our guide, we see at a glance, as before remarked, that so far as the yield of wheat was concerned, in 1871 and 1874 , the depredations of the chinch-bug in the States named, althongh these are the ones in which it was most abundaut, had no marked effect. Althongh the aggregate amount produced in 1871 was a little less than that of 1870 or 1872 , yet the yicld per acre was actnally a little more than in 1872, and but three-fifths of a bushcl less than that of 1870 . It is, therefore, more than probable that the calcnlations of Dr. Le Baron and others in reference to the loss on wheat in 1871 is largely in excess of the eorrect amount, and was probably made np chiefly from the ginesses of correspondents, and assuming the destrnction was equal in all parts of the area cmbraced. The same thing may be said in refercuce to the calcnlations of Dr. Shimer and others in reference to the loss in 1864 , for in Illinois, to which State these chicfly referred, the vicld of wheat in 1864 was, according to the statistical report, actually 3.5 bushels more per acre than in $186 \tilde{3}$, and the total amount nearly $8,000,000$ bushels more; but in reference to corn the case was reversed. In these earlier calculations another cause of error arose from the fact that no reference was made to these statistical reports as checks and guides. I have no doubt but that the loss occasioncd by this insect in $187+$ was far greater than in auy previous year, yet Mr. Riley in reference to Missonri, and the writer in reference to Illinois, applying these checks so as to elimi nate crror as far as possible, although finding the loss truly alarming, producerl no such fignres as the calculations relating to 1864 and 1871 . We also fonnd that the loss on wheat was confined chiefly to the spring variety, and was really mnch less than had been supposed, though of 
sufficient inportance to demand the attention of agrienltmists and the govermment, running up in some years to millions of dollars. For, notwithstanding the showing of the statistical report, that this insect did, in 1864, 1871, and 1874, destroy large amonnts of wheat, especially in the spring-wheat belt, is too well known to be controverted by any statistics.

There are strong reasons for believing that the habits of the species have sontewhat changeil since it first cane into notice as injurions; so that instead of being more destrnetive to the wheat-erop, as formerly, it is now more injurions to corn. A farmer writing to the Prairie Firmer, Octolner 18, 1873, makes the following statement on this point:

"I bave, as a farmer, suffered fiom the ravages of the chinch-bng for twenty-eight years; it has steadily increased in numbers. While ut first it only injured outs and spring-elheat, it now swarms in onr cor'tlfiekls and injures onr fall wheat. * * * I have seen corn not more than six inches high destroged by them. Years ago it was generally thought, where I then resided, that we should have to stop laising suring. wheat to get clear of them, as it was then the only crop seriously injured; now we wonld have to make onl land a desert to starve then ont."

If we tmon now to the corn statisties we shall find that so fall as the Nortluwest is concerned this is the erop that sulfers most from this pest, and that in some years the loss, estimated by the most earefinl rules, is absolntely enormons.

Even in 18 it the effect of this insect on this crop is manifest in the statistics; to show this we present a table showing the production of the States named, for the years 1864 and 1865.

Total yicld of corn.

States.

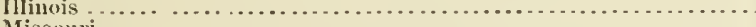

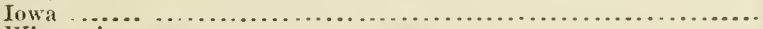

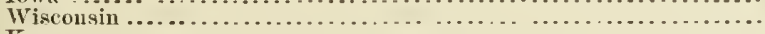

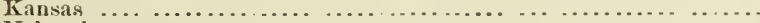

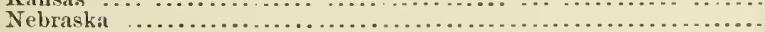

Total
1864.

Bushels.

$74,284,363$

$138,356,135$

$36,635,011$

$55,261,240$

$10,087,053$

4. 673,081

$1,366,622$

$320,663,505$
1865.

Biushels.

$116,069,316$

$177,095,852$

$52,021,715$

$62,997,813$

$13,449,405$

6. 729,236

$2,494,084$

$430,857,421$

Tield of corn per acre.

States.

Indiana

Illinois

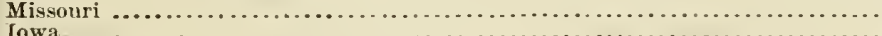

Wisconsin

Kansas...

Nebraska.

A rerage by States

\begin{tabular}{c|c}
1864. & 1865. \\
Bushels. & Bushels. \\
29 & 40.6 \\
33 & 35.2 \\
26.8 & 39 \\
36.7 & 42.7 \\
31 & 41.5 \\
25 & 41.2 \\
28.5 & 46.5 \\
\hline 30 & $-\frac{40.95}{}$
\end{tabular}


Hese we see a difference of 10 bushels per acre in favor of 1865 , showing a loss in 1861, after allowing for the difference in acreage, of about $100,000,000$ bushels, which was largely owing to the chinch-bug.

The statisties of 1871 , it is true, fail to show any marked loss ; in fact, the yield per acre, as shown, was larger this year than in 1870 or 1872 , but there was evidently some change in the method of computing the ereage, probably canse d by the census returns for 1870 , and hence it is mpossible to make a true comparison in this respect. But even making allowances for this, the loss in the corn-crop does not appear to have been severe except in Indiana, which could not have been very largely owing to the depredations of the chinch-bug.

On the contrary, the statisties for 1873,1874 , and 1875 , as above given, bring ont very clearly the loss in $187 t$ to this crop. The yield per acre in 1874 was nearly 10 bushels less than in 1873 and nearly 15 bushel $_{S}$ less than in 1875 . If we take the acreage in 1874 and estimate the yield at but 30 bushels per acre, which is but seven-tenths of a bushel more than in 1873 and nearly 42 less than in 1875 , we shall find the aggregate loss to have been a little over $200,000,000$ bushels. By comparison with the loss on this crop in other States in 1874 , we find that about 40 per cent. of it is to be attributed to the drought of that scason, the renraining 60 per cent. almost entirely to insects, the chinch-bug and grasshoppers, or locusts. Here, then, is a loss on corn alone in these seren States in one season by insects of some forty or fifty millions of dollars. Indiana, Illinois, Wisconsin, Eastem Missonri, and Eastern Iowa sus. tained more than two-thirds of the entire loss, and this was occasioned by the chinch-bug.

It is evident, therefore, from these faets, that while the loss to the wheat-crop occasioned by this insect is large, it is greatly exeeeded by that to the corn-crop.

Let us now return to the consideration of the means to be adopted for their destruction and preventing their depredations.

Burning.-As the bngs from which the future generations are to be developed hibernate in the perfect state, as has heretofore been shown, it is evident that if these ean be destroyed their development will be prevented, and for each female destroyed, whieh sex is largely in excess of the males at this season, numbers of the spring brood will virtually be exterminated. It should also be remembered that at this time their number is reduced to a minimum and that they are quiescent. If it is possible, therefore, to reaeh their retreat with fire, this will be the most effectual metlod of destroying them where irrigation is impracticable.

But Dr. Te Baron, as we have seen, believes this will be ineffectual, because the bugs, as he finds, do not remain on the cornstalks during the winter, but seek other quarters in whieh to hibernate. That they do so where the corn is not cut and shocked is nudonbtedly true to a very large extent. I have also observed the same fact, mentioned by Mr. Patten, that to a large extent those fomm after winter sets in under 
slieaths of the lower joints of the stalks arc gencrally dead. These, I think, are ehiefly the males; possibly they are, as he suggests, in part, at least, the old ones of the preceding brood. Although, when hatd pressed, they sometimes hide beneath the clods, yet this is the exception and not the rule; they seek shelter wherever it can be found in and around the field. So far, thercfore, as it is possible to do so, fire should be carried to these snrrounding hiding-places. In timbered sections the leares should be burnch, and, as was Mr. Nichols's custon, the fence corner's should be cleanerl and burned. Although a large number, on accomnt of the impossibility of reaching them, will ascape, yet, if this methou is thoroughly earried out, the greater portion will be destroyed.

But in order that this remedy may be effectual all the fimers in the infested ristrict must act in concert, otherwise the labor of one will be rendered valueless by. the negleet of another.

In order that this concert of action may be brought abont, it might be well for the States infesterl by this pest to endet laws giving the officers of towns or connties authority when danger was apprelnended to compel action. But this ncel not be done ammully, as our knowledge of the labits of the inseet is sufficient, if properly used, to give us warning of the danger. Two successive favorable-tlat is, dry-years are reouired to develop them in sufficient numbers to canse any serious injury. In the winter following a lainy season they will be redueed to a minimum in respect to number's, and although the following scason may be dry, they cannot increase to the same extent possible when two farorable seasoms comc in snceession. The second lrood may expite some alam, but it will not be sufficiently numerous to inflict any serious injury. It is also evident that four successive broods, withont any comnteracting influence to cheek them, will prorluce more than two broods.

If the season has been hy, and an examination in the fall shows them to be present in considerable numbers, although they have dome no ma. terial injury nor even attracted general attention, yet it may be set down as pobable, in faet almost certain, that if the next is try, unless killed by an unusual winter, they nay be expected in lestructive numbers. It is true that they somctimes appear in great numbers when no complaint has been made the previous scason; but if a careful examination had been male the numbers hidlen from the ensory glance would have caused apprehension of danger.

If the season is wet examination is mmecessary, but if it is dry search for them should be madc by every farmer in the fall before cold weather sets in, and in and around every field where found, as soon as it is possible to do so, every hiding place should be subjected to a fiery ordeal. Dr. Le Baron suggests that the farmers need the stalks for fodder, but it is better to sacrifice them one season than to abstain from sowing sinall graiu.

When they are in sufficient numbers to do serious injury or excite apprehension of danger from them the next season, it might be well to adopt 
the sonthern plan of topping the corn. This will cause the grain to harden more rapidly and the stalk to dry the sooner, so that the corn can be gathered at an earlier day, when the stalks can be cnt and raked into windrows and burned before the bngs liave left them.

Mr. Riley recommends that "shocks shonld be made at intervals to. attract the bugs. The bngs will then congregate in these shoeks, which may be burned at any time during the winter"-after the ears liave been removed. As confirming this opinion he quotes the following from a letter of one of his correspondents: "The most compact and destructive army of chinch-bngs I ever saw started from sorghnm bagasse which had been used as manure. Might the insects be trapped to any extent worth mentioning by exposing heaps of rubbish in conspicuous places in Aligist, and burning the same in November"?

If it is found at the time wheat is harvested that the bugs have not taken their departure, as is the case in the wutcr-wheat section, this fact nac be taken advantage of to destroy a very large portion of them. If the wheat is at onee threshed and the straw scattered over the stubble and bmmed it will destroy all or most of those that are there. I know of one section in Sonthern Illinois where this has been practiced for a number of sears by the German farmers with good results.

Finther information is clesired in reference to the time the migrations. take place in the different sections of the comntry, espeeially whether this is usually before or after wheat harvest. As there is a difference in this respect, it is desirable to ascertain the boundary line between the sections; to know whether it varies according to kind of wheat that is raiser, spring or winter, or aceorling to latitnde.

It wonld seem that a thing apparentiy so easily ascertained, and which has been so often observed, ought to be generally known; but it appears to have been overlooked by those writing in reference to the chinch-bug and its habits.

My personal observations of the habits of the species have been confined to the winter-wheat belt, where it is usnally, and so far as 'I know universally, the case that they migrate after harvest. This fact should therefore be taken advantage of by the farmers withiu that region, as it aftords them an excellent means of destroying this pest.

ABSTAINING FROM THE CULTIVATION OF GRAIN FOR ONE OR TWO. SEASONS.

This measnre is somewhat fully disenssed by Dr. Le Baron in the extract heretofore given from his second report. His suggestion only ap. plies to the small graius and chiefly to spring wheat. But aside from the impossibility of carrying ont this plan, I have serious doubts whether it will be of any real advantage if we take into consideration the loss of the crop. That it will be of no permanent benefit I think must be admitted by every one who is acquainted with the habits of the species. However, as re:nurked by the Prairie Farmer correspondent, whose 
words have been already quoted, in order that this remedy be made effectual it would be necessary to transform our land into a desert.

It is unnecessary, therefore, to discuss this remedy.

RoLLING.-Mr. Riley makes the following remarks in reference to this remedy :

"As the mother chinch-bng has to work her way under gromul in the spring of the year, in order to get at the roots upon which she proposes to lay her eggs, it becomes evident at once that the looser the soil is at this time of the year the grcater the facilities which are offered for the opcration. Hence the great advantage of plowing land for spring grain in the preceding autumn, or, if plowed in the spring, rolling it repeatedly with a heavy roller after seeding. And hence the remark frequently made by farmers, that wheat harrowed in mon old corn ground, without any plowing at all, is fur less infested by chinch-bug than wheat upon land that has been plowed."

EARLY sowing.-As Dr. Le Baron has discussed this proposed meas. ure some what thoroughly, it is mnnecessary for me to advert to it exeept to ard that it might be well for the furmer in the nort hern portion of the chinch-bug belt to push the line of winter wheat as far northward as possible. By judicious selections it may be possible to obtain varieties which will be adapted to more northeru climates than those now in use. There are some objections to this which may possibly outweigh the supposed advantage; one is the greater liability to injury by the HessianHy.

So far as corn is concerned, I believe that as a rule which has but few exceptions the sooner it is planted after the spre ing is fairly opened, and the ground is properly prepared, the better.

The more vigorous the growth of either crop the less will be the injury by the bug; even if they could exist in a damp season when the plants are strong and healthy, the damage oceasioned by them would be slight compared to what it is in a dry year when the plants are enfeebled by a lack of moisture. On this account it is desirable that the hardiest varieties, or such as ean best withstand drought, should be used.

OTHER REMEDIEs.- It has been suggested that it might be of adrantage to sow a strip of spring wheat around a field of winter wheat, so that when the bugs have sucked it dry, or as soon as the winter wheat is ent, and before the bugs have commenced to migrate to the corn, the spring wheat may be burned.

Some have tried surrounding other erops with Hungarian grass or millet, hoping to retain the bugs in it; but none of these expedients have proven of sufficient advantage to warrant the trouble and expense. Now and then there has been an exception, but the result has generally been as stated.

Topical remedies, such as the application of lime, salt, tarred sawdust, and other similar substances, will prove, as Dr. Le Barou has well remarked, "labor lost." That it is possible to destroy them by the use 
of hot water and certain acrid liquid substances is moubtedly true, but such remedies ean be profitably used only on a small scale, as in the garden. Thorough drenching with water at the proper season, as recommended by Dr. Fitch will also destroy them; but all such remedies are inapplicable to field cnlture, as the expense wonld far exceed the value of the crop to be raised.

REMEDIES FOR TIE PROTECTION OF THE CORN CROP.-Fortunately for the farmer, nature has so arranged it that the summer brood, when compelled to migrate in search of food, either from necessity or preference, move on foot. As they all go together or in bodies when the nurement commences, and nsually in the same direction, it is apparent that if an obstrnetion of any kind ean be placed in their way so as to retard their progress this will mass them in a comparatively small spaee and render their destruetion mueh easier than when scattered through the fields. If the obstruction can be made to effeetually bar their progress, they will be compelled to seek food elsewhere or perish. Farmers aware of this faet fiom their observations have had recourse to a number of expedients to accomplish this desired end to save their corn crop, which is the one that chiefly suffers from the migrating hordes.

One of the devices employed is to set np boards edgewise aromd the field or along the side which the bugs are approaching and besmear them with tar or kerosene. As this plan is described in Dr. Le Baron's notes, already quoted, it is umecessary to note it farther than to say that although, perbajs, one of the most effectual bars to their progress, the expense and diffieulty, in some places, of procuring plank and tar just at the time ther are needed will prevent its being extensively adopted.

Another and more common method of stopling their progress is to plow a narrow strip around the field, keep it well pulverized by harrowing and rolling, then plow one or two furows in this dusty strip. This should be done every day or two, care being taken to keep the strip as thoroughly pulverized as possible, as the bugs caunot travel well throngh the dust. The philosophy of this plan is, that as the bngs attempt to crawl up the sides of the dusty furrows the loose particles give way, and they roll back to the bottom. If they accumulate in the furrows a $\log$ or stone must be drawn throngh them so as to crush and destroy them. As it is always, probably without exception, dry weather when they migrate and the soil dry, it is not difficult to keep the plowed strip pulverized if the clods are well erushed at first by rolling with a heary roller where the soil is clayey.

Ditehing is sometimes resorted to, but in this case care should be taken to have the side next the field perpendicular, and it wonld be well to drag a stone, log. or bundle of brush through it as soon as made, so as to rub the sides and somewhat pulverize them or render them dusty.

As they generally confine their operations for a time to the first few rows of corn of the field they attack, it is possible to destroy a large number of them by applying hot water, and this has in some instanees 
been successfully practiced, bnt the labor and expense are generally too great to justify it.

Renarks.-Clean farming is the best under all circumstanees, and, if aclopted as a rule, will tend largely toward preventing the increase not only of chinch-bugs, bnt of all other injurious inseets that tronble the farmer. But one of the best methods of preventing their increase is diversified farming. Massing erops in immense bodies and enltivating the same thing year after year on the same gromnd, as is so often done, necessarily tends to increase the insects that feed on these crops. An increase in one loeality of any one plant hrings a proportional increase of its insect enemies as a direct effect, and these are increased in a geometrical ratio if the plant is allowed to oecmpy the same locality for a number of seasons in snceession. The only offiset in this ease is a like increase of the peculiar parasites that prey upon these insects, but in the ease of the chinch-bug nature has farored man with no sueh friends, as it has no true parasite. So long as this violation of natural laws and, I mightsay, of the true theory of the furmer's profession is continued, so long will it be necessary to war with increasing hosts of inseet foes. Enlarging farms and increasing crops will of neressity bring these evils; re. verse the system, divide the farms, and diversify the farming, and it will be far less diffienlt for the farmers to cope with their insect foes. The disposition in our country, especially in the West and Sonth, to obtain and operate large farms by machinery, is one of the evils of our agrienltural system. It is to our interest as a natiom to multiply farms, to divide the land into as small parcels as possible, to draw the population

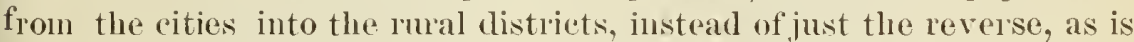
the effect of the present system. Small farms and diversified farming is one of the best means not only of counteracting the numerous insect foes with which the farmers have to contend, bnt also to alleviate or prerent a number of other evils which society has to suffer. Bnt 1 fear it will be more difficult to bring abont this state of things than even to put into operation Dr. LelBaron's suggestion.

Before closing, I wonld call the attention of those agrienlturist into whose hands this Bulletin may fall to the fact that there are other species of insects which are sometines mistaken for the chinch-bug. These are generally of the same order or sub-order as that to which the chinch-bug belongs, viz: Heteroptera. The one which bears the strong est resemblance to this noted pest is the false chinch-bng (Nysius destructor Riley, Fig. 9). This species appears to have fully as wide a range as the true chinch-bug and over the same area. In the perfect state it is shaped much like the true chinch-bug, and bears a somewhat strong general resemblance to it, though differing naterially when closely examined. It varies in length from one-tenth to one-eighth of an inch to the tips of the wings, is of a gray. False Chinch-bug. - b, pupa; $c$, ma-

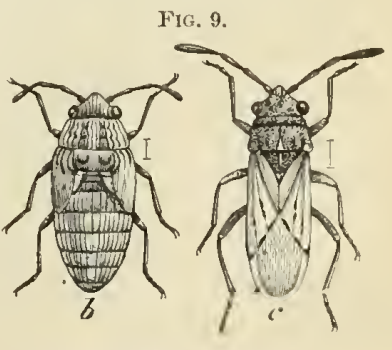


ish-brown color, the antennæ pale, with the fourth joint enlarged and as

Fig. 10.

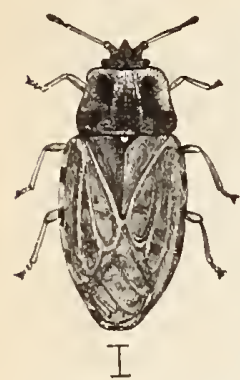
long as the third; the elytra or upper wings pale, and usually more or less tinged with dirty yellow on the basal portion; the legs pale yellowish, with brownish thighs. Like the true bug, it hibernates in the perfect state. In the summer it is frequently found on various wild flowers and small fruits. It is also fond of purslane.

A second species, the ash-gray leaf-bug (Piesma cinerea Sas, Fig. 10), according to Mr. Riley, is also often mistaken for the chinch-bug. It is of a greenish-gray Ash-gras Leaf-bug. color, about one-sixth of an inch long, and is flatter and broader than the true pest.

As one object of this bulletin is to call attention to this injurious insect and gather facts for a further report, it is hoped that any one into whose hands a copy may fall who has information to communicate, will do so by addressing the writer at Carbondale, Illinois. 
